\title{
Identifying Forward and Backward Linkages From China's Infrastructure Investment in Africa
}

Ehizuelen Michael Mitchell Omoruyi, Center for Nigerian Studies under the Institute of African Studies, Zhejiang Normal University, China

\begin{abstract}
The continent of Africa must industrialize to eradicate poverty and create jobs for its 12 million African youth who join its workforce yearly. One of the major factors hindering industrialization has been the insufficient stock of productive infrastructure that would permit companies to thrive in industries with robust comparative advantage. Within the context of Africa-China cooperation, China has emerged as a key partner to several African nations, including financing as well as constructing large-scale infrastructure projects. With emphasis on the Tazara railway, Mombasa-Nairobi railway, and Ghana Bui hydropower dam, this paper employs backward and forward linkages theory to investigate what role these three Chinese-led infrastructure projects play in African infrastructure development and what the infrastructure investment leads to concerning creating new opportunities and businesses for Africa. The paper discovers that these three Chinese-led infrastructure projects have multiple gains and linkages for and beyond the three various projects areas. Above all, these three Chinese-led infrastructure projects were seen by the Chinese government to fulfil its goals in Africa.
\end{abstract}

\section{KEYWORDS}

Africa, Backward, China, Financing, Forward Linkages, Infrastructure

\section{INTRODUCTION}

Five of the top ten fastest growing economies in the world in 2019 are in Africa, and four in SubSaharan Africa (SSA) (Deloitte, 2019). Yet, for GDP growth to produce structural changes required across Africa, it needs to be inclusive. Essentially, more focus must be placed not only on quantity (high growth) but also on the qualitative aspect of growth. All these can be possible if African economies invest more in infrastructure. This is because infrastructure holds a transformative power in the global economy. No wonder the Chinese proverb says: "If you want to prosper, first build roads" (Deloitte, 2018). That was why when China launched its own economic development it built roads, ports, rural power plants, modernized agriculture, invited in factories and experimented with different approaches: special economic zones for instance. The Chinese did this because they know that through the construction of electricity, roads, ports, airports, railways, and communications networks, nations can power the homes of their citizens and commerce, connect producers to markets, and share information speedily, thereby boosting worldwide and regional trade, competitiveness, economic opportunities, and the quality of life (Sy, 2017).

With that said, notably, better infrastructure can benefit African the economy through these three channels. Firstly, cheaper transport costs can help create new markets and realize the return 
to agglomeration, which in turn fosters competition, spurs innovation, lower prices, and raises productivity, thereby leading to a surge in the standard of living (Henckel and McKibbin, 2010). Secondly, transport infrastructure can have a direct effect on the economic efficiency of an economy by reducing transport costs and an indirect effect by lowering inventories. Thirdly, as an economy moves up the global value chain, adapting its infrastructure can be a catalyst for promoting private activities and industrialization, and ensuring that enough employment is created for the 12 million young African youth entering the labor force yearly, ${ }^{1}$ attracting foreign investment in other sectors and increasing business confidence, fosters innovation and productivity, promote the manufacturing sector, skills development, integration, intra-African trade, tourism, competitiveness, economic opportunities, quality of life and leading to more trade with the rest of the world. This shows that infrastructure can help propel FDI and in turn help to develop forward and backward linkages which will permit domestic companies to be better integrated into global supply chains.

With that said, Mckinsey Global Institute (MGI) estimates that infrastructure typically has a socioeconomic rate of return of around 20 percent (MGI, 2016). In other words, one dollar of infrastructure investment can raise GDP by 20 cents eventually. Simulations show that in developing nations, increasing the public-investment-to-GDP ratio from 7.0 percent of GDP to 14.0 percent of GDP in about three years and stabilizing it at 9.0 percent of GDP afterwards can substantially raise the output by 7.0 percent over the long term (IMF, 2014). ${ }^{2}$ The potential benefits of infrastructure are even larger when the network and cross-sectoral impacts and synergies are accounted for. The World Bank estimates that SSA gross domestic product (GDP) per capita growth would surge by 1.7 percentage point yearly if the region were to close the infrastructure gap (in terms of both quantity and quality) relative to the developing world median. ${ }^{3}$

No wonder Park (1989) has confirmed that the infrastructure industry generates one of the highest multiplier effects through its extensive backward and forward linkages with other sectors of the economy. As such, for a nation to develop that nation needs to first move for developing infrastructure facilities to the backward regions of the nation to boost up the economic performance of that nation by means of facilitating major economic activities, namely agriculture, industry and service. Also, the nation follows the same path and try to invest further so that there is a parallel surge in the levels of investment expenditures which accelerate the process of growth and development of the economy. The former one is known as the forward linkage and the latter is known as the backward linkage.

On the other hand, concerning forward and backward linkages, infrastructure can raise the productivity of other factors of production. For instance, installation of a novel irrigation system can improve the quality of farmland, therefore, raising productivity per hectare and shifting the production possibility curve outward (Todaro \& Smith, 2009). The higher productivity, in turn, attracts more resources (private investment) into production, which further contributes to higher levels of output, the profitability of production, income and employment in these sectors. This indicates that a combination of these two repercussions may happen when investment by one sector leads to investment by other sectors in a parallel way and to say in other ways that the forward and backward linkages work side by side that may ensure the overall growth and development of a nation. Notably, the importance of the infrastructure sector stems from its strong linkages with other sectors of the economy (World Bank, 1984). This means that the proper working of both linkages generally accepted as a catalyst to development and the sound bases of the infrastructural facilities in most cases defend the economies from any global shocks.

With the above forward and backward linkages, there is a need for urgent implementation of reforms to improve institutions that foster private sector growth, develop local capital markets, strengthen domestic resource mobilization, and improve infrastructure. This could also make growth in Africa more inclusive, reducing poverty across Africa and promoting the world shared prosperity, especially African nations. Therefore, infrastructure is featured in Goal 9 of the 17 Sustainable Development Goals (SDGs) of the 2030 Agenda - "Build resilient infrastructure, promote sustainable industrialization and foster innovation" and Aspiration 2 of Agenda 2063, the African Union's vision 
for Africa's transformation over the next five decades. As such, scaling up infrastructure investment in the region could help attain much needed higher growth.

With that said, notably, regional institutions, including the African Development Bank (AfDB), the New Partnership for Africa's Development (NEPAD), and the United Nation Economic Commission for Africa are actively supporting infrastructure development in the continent, there is the possibility that meeting the SDGs of 2030 and African Agenda 2063 will require a decisive action as Africa's infrastructure needs remain immense. For example, Sy (2017) claims that only 30 percent of Africa's population has access to electricity, 34 percent has access to roads, and the internet penetration rate is wobbly low, a mere 6 percent compared with 70-90 percent for other developing nations. The author added that in sub-Saharan Africa (SSA), the infrastructure deficit is particularly acute, with the poorest nations in Africa falling far below other low-income nations on all infrastructure-related indicators.

To address the continent infrastructure deficit and completely attain Goal 9 of the SDGs and Aspiration 2 of Agenda 2063, governments will need to accelerate and intensify efforts to mobilize domestic and external funding resources for infrastructure development. Notably, SSA nations spend almost US\$60 billion from their national budgets on infrastructure development in 2012 (Sy, 2017). Although this amount is significant, this amount falls short of the recent estimate by the African Development Bank (AfDB) that put the continent's minimum infrastructure needs - for nations to sustain the growth of their economies, population, income level and replace ageing infrastructure at US $\$ 130$ billion to US $\$ 170$ billion yearly; at least half of that requirement is recently unfinanced (AfDB, 2018).

So, where can African governments find the necessary funding to carry out these projects? A substantial portion of these investments are now coming from African governments, donors (ICA members), and non-traditional sources: The private sector and emerging nations, especially China (see Table 1) (Foster et al., 2008; UNCTAD, 2008; Moyo, 2009; AfDB, 2018). African nations are now seeking financial resources well beyond foreign aid; as a result, this opens up opportunities for possible Africa-China Cooperation.

Table 1. Trends in Infrastructure Finance in Africa, by Source (\$ billion)

\begin{tabular}{|l|l|l|l|l|l|l|}
\hline \multicolumn{1}{|c|}{ Source } & \multicolumn{1}{|c|}{$\mathbf{2 0 1 2}$} & \multicolumn{1}{c|}{$\mathbf{2 0 1 3}$} & \multicolumn{1}{c|}{$\mathbf{2 0 1 4}$} & \multicolumn{1}{c|}{$\mathbf{2 0 1 5}$} & \multicolumn{1}{c|}{$\mathbf{2 0 1 6}$} & \multicolumn{1}{c|}{ Average } \\
\hline African governments & 26.3 & 30.5 & 43.6 & 24 & 26.3 & 30.1 \\
\hline Donors (ICA members) & 18.7 & 25.3 & 18.8 & 19.8 & 18.6 & 20.2 \\
\hline MDBs and other bilaterals & 1.7 & 2 & 3.5 & 2.4 & 3.1 & 2.5 \\
\hline China & 13.7 & 13.4 & 3.1 & 20.9 & 6.4 & 11.5 \\
\hline Arab nations & 5.2 & 3.3 & 3.4 & 4.4 & 5.5 & 4.4 \\
\hline Private sector & 9.5 & 8.8 & 2.9 & 7.4 & 2.6 & 6.2 \\
\hline Total & 75.1 & 83.3 & 75.4 & 78.9 & 62.5 & 75.0 \\
\hline
\end{tabular}

Source: The Infrastructure Consortium for Africa (ICA) 2017; AfDB, 2018

With a focus on these three Chinese-led infrastructure projects - Tazara railway, Mombasa-Nairobi railway, and Ghana Bui hydropower dam, this paper employs backward and forward linkages theory to investigate what these three Chinese-led infrastructure projects have led to concerning creating new opportunities and businesses for the continent of Africa. As such, the paper mostly relies on multiple data sources such as archives, second-hand materials, and international organizations reports that have already been undertaken on this topic to elucidate and comprehend the existing process of Africa-China cooperation by focusing on infrastructure projects. 
The in-depth part of this paper will be the case studies of the Tazara railway, Mombasa-Nairobi railway, and Ghana Bui hydropower dam that illustrate a small part of the reality of this topic. From these case studies, identification of linkages will be offered and deliberated on. Therefore, one of the significant aims of this paper is to identify linkages that emerge from infrastructure projects in Africa coming from China. It is in this context the author analyzes the linkage development as a window of opportunity for Africa's infrastructure investment.

\section{LINKAGE DEVELOPMENT AS A WINDOW OF OPPORTUNITY FOR AFRICA'S INFRASTRUCTURE INVESTMENT}

This paper is framed by the concept of backward and forward linkages theory. Backward linkages are established when the growth of one industry leads to growth among supplying industries, while forward linkages evolve when the growth of one industry leads to the growth of industries that use their outputs as inputs. More so, backward linkages create additional demand for the output of upstream sectors which, in turn, induces an augmented upstream investment and an augmented level of capacity utilization, as well as a possible upstream technological upgrading. The overall effect on the economy depends on the type of sectors to which a sector backwardly connects (Tregenna, 2008). By contrast, the forward linkages of a sector impact downstream sectors. Therefore, decreasing costs of a sector's output can result in growth-inducing effects on downstream industries. These could comprise downstream investment, technological upgrading, or augmented productivity and resource utilization. Both these growth inducing mechanisms - backward and forward linkages -are so-called Hirschman-type production linkages (Tregenna, 2008).

The concept of backward and forward linkages was introduced by Albert Hirschman (Hirschman, 1969); development planners have long used the concept to investigates these interactions. However, few analysts have a focus on infrastructure development. Basically, what it does is that it tries to describe the economic connection between the buyer and the producer (Guo, 2013). In other words, a linkage exists whenever an ongoing activity give rise to economic or other pressures that lead to the taking of new activity (Sender and Smith, 1986). The linkages recognized in the economic literature over the years comprise of those arising directly from the production (backward, forward and sideways linkages), and consumption or demand, but also from infrastructural externalities, lateral migration of technologies and fiscal revenues (Hirschman 1958; 1981; Mtegha et al., 2012; Walker and Jourdan, 2003). Some nations have been more successful in ensuring that linkages materialize than others and this is tied to the mechanism that is used, or agency. The relationship between linkages and agency (not necessarily the state) determines the system of accumulation of economies which in turn shapes the structure of the economy (Fine and Rustomjee, 1996).

Nowadays, it has been said that usually, the project produces linkages and the theory argues that the more linkages a project creates the better it is and, therefore, most investments should be boosted into that certain project than anywhere else. An obvious instance to describe these linkages is by using the instance of the steel industry provided by Dadvar (2016) where the backward linkages are coal and iron mining and forward linkages are, for example, canned goods. When trying to understand a long-term, ongoing process like infrastructure project this theory can be a good way to demonstrate in real terms what these projects result in (Hirschman, 1969).

In terms of what these infrastructure projects produce, the continent of Africa needs to provide job opportunities to millions of young inhabitants, open intra-trade as well as international trade routes and provide the best opportunity for African nations to lift themselves out of the traps of isolation, poverty, and marginalization. Only massive investment in infrastructure can create the window of opportunity required to maximize profit, minimize cost, create multiplier effects and open opportunities that enable the activities of other sectors like tourism, agriculture, extractive and industrial sectors to function and, in turn, allows the continent of Africa to eradicate poverty and attain sustainable development. Simultaneously, this will help facilitate dynamic processes of technological innovation, 
skills development, knowledge-intensification and capital accumulation. Linkage development in infrastructure investment can open vital opportunities in this respect.

By advancing backward and forward linkages to the infrastructure sector, African nations can maximize direct and indirect job creation effects. On top of that, steady increases in linkage development can offer significant opportunities for African nations labor-intensive and small-scale enterprises, employing semi-skilled and casual workers, help small and medium-sized enterprises overcome frequent transaction costs, electricity and water outage that usually create barriers for firms to enter markets and raise entrepreneurship, ultimately affecting household income growth, consumption, and vulnerability to macroeconomic shocks. Moreover, as for soft infrastructure sectors, construction firms can stimulate local employment but also generate spillover effects, such as skills development, management experience, and technology transfer. For soft commodity sectors, resource-processing industries can bolster raw material supplies, ${ }^{4}$ which create further job opportunities in the agricultural sector. However, all these opportunities in resource-processing industries need infrastructure such as railway, roads, water, ports, communication, power grids and service providers such as transporters to function which work as both forward and backward linkages. Therefore, developing backward and forward linkages to the infrastructure sectors can contribute to development of African economies. This is because, by integrating forward linkages with good infrastructure in place, African nations can anticipate accruing higher export revenues and foreign earnings (Morris and Fessehaie, 2014).

In the global arena, infrastructure is essential for participation in global value chains (GVC) to upgrade the economic structure. GVCs refer to the diverse value-added connections, composed of several activities, required to bring a product from conception and design to its delivery to the final consumer and, finally, to its disposal (Kaplinsky and Morris, 2001). This GVCs offer opportunity for least developed nations to alleviate poverty by snowballing income and creating employment. Kummritz et al. (2017) discovered both backward and forward GVCs participation can lead to the growth of domestic added value, based on a data set covering 61 nations and 34 industries between 1995 and 2001. Improving infrastructure, including hard infrastructure and soft infrastructure, is a necessary condition for reaping the benefit from the participation in GVCs to upgrade the economic structure. Reliable infrastructure to connect supply, and efficient movement of goods and services across borders, fast and reliable information transfer, and sufficiently low coordination costs are prerequisites for participating in GVCs. As argued in the World Bank Report Transformation through Infrastructure, infrastructure development is critical to delivering growth, reducing poverty, addressing transaction costs and broader development goals (World Bank, 2012).

Linkages from infrastructure development can help propel industrial development and this industrial development can open opportunities for positive externalities that are hard to quantify. With infrastructure development, African nations can promote diversification of technological capabilities and of their skills base by developing backward linkage supply companies to the commodity sectors and resource-processing industries. Also, because the natural resource sector usually requires the development of infrastructure to extract and transport the overwhelming bulk commodities, potential for linkages is enhanced. This tends to occur more frequently with a high volume of mineral resources which generally needs highways and railways. As these are developed it turns out to be easier to advance supplier and resource-processing activities, which in turn raise the economies of scope ${ }^{5}$ as for further infrastructure development. This positive externality, however, is uncommon in the case of commodities like oil, gold and diamonds, which promote enclave-kind infrastructure (Perkins and Robbins, 2011). For those linkages involving knowledge-intensive services, the key elements of infrastructure are likely to be telecommunications, security and air transport, whereas the provision of tangible inputs into the commodities sector and the processing of the output of the commodities sector are most likely to require hard infrastructure such as roads and rail.

With that said, the evidence above indicates that there has been a steady upsurge in linkage development and that there are significant opportunities for deepening this process. As such, if the process is deepened, linkage development can also create the opportunity to maximize positive 
externalities derived from clusters. When supplier and resource-processing industries are having good infrastructure such as constant electricity, good roads, and being positioned close to the extraction location, there are agglomeration effects. ${ }^{6}$ The processes of agglomeration are backed by public infrastructure, particularly in the transport sector. Back to the cluster aspect, nevertheless, efficiency benefits from companies situated in cluster include gaining access to a pool of labor, and to specialized network suppliers. This is specifically vital for the continent of Africa. By promoting specialized supply networks, buyers accrue advantages in terms of lowering transaction costs, reducing stocks, shortening delivery times, and snowballing flexibly to adjust to novel products. Hence infrastructure plays a critical role in all these processes reaching the market and in providing the necessary inputs for production.

Based on linkage development, Krugman (1991) displays that manufacturing companies tend to locate in regions with larger market demands to realize scale economies and minimize transportation costs. Low transport costs permit larger scale production, which in turn creates investment activities in other industries. From the development viewpoint, one of the most vital features of any industry is the extent to which it can generate demand for the products of other industries. An industry may encourage investment both in the subsequent stages of production by forward linkage and in earlier stages through backward linkage. This creates employment, generates incomes and triggers spillover into rural, services and supplying sectors; this is particularly vital for Africa.

Furthermore, speaking in more contemporary terms of development that circles very much around development assistance, so as for these investments to contribute to an industrial transformation it requires to substitute for backward and forward linkages (Brautigam, 2009). There is a general agreement in development literature that basic infrastructure - ranging from transport and power to water, sewage systems and telecommunications - is a prerequisite for development and, moreover, for any economy to function. No wonder Brautigam (2019) citing Drown (2011) statement asserts that when Ngozi Okonjo-Iweala, a vice president of the World Bank and former finance minister of Nigeria, asked the Chinese how Nigeria could attain 10 percent growth like China, they replied: 'Infrastructure - infrastructure and discipline'. This is particularly relevant in the early stages of development, when provision of infrastructure generates its own linkages within the domestic economy.

\section{THE STATE OF INFRASTRUCTURE IN AFRICA}

The positive impact of physical infrastructure on economic prosperity and business is well identified. Improved infrastructure services such as transport, electricity, telecommunications, sanitation and sewerage systems positively affect productivity and encourage more regional integration and trade. Africa has recently experienced substantial economic growth, with an average annual growth rate of 4.7 percent between 2000 and 2017 (AUC/OECD, 2018). Simulations propose that improving Africa's infrastructure could boost GDP growth by an additional 2.2 percent a year (Foster and Briceno-Garmendia, 2010). Increased access to infrastructure can also facilitate more intra-regional trade, particularly following the signing of the African Continental Free Trade Area (AfCFTA) pact in March 2018. In 2015, intra-African trade represented 18 percent of total exports in Africa, a 10 percent surge since 1995, although still a relatively low figure by comparison with Asia and Europe. Intra-regional trade for these areas stands at 59 percent and 69 percent respectively (Sow, 2018).

Improving connectivity is also essential to enhance Africa's integration into regional and global value chains. Effective and efficient transport networks enable firms to reach out to regional and international markets at a lower cost. In addition to faster delivery of goods through improved crossborder roads, railways, and international ports and airports, African nations could import raw materials and intermediate goods more cheaply and export manufactured products more competitively.

In other cases, physical infrastructure can also serve the requirements of other sectors, users and producers - this is broadly known as 'corridor development'. Speaking of a corridor development, India EXIM Bank (2018) report citing the World Bank has estimated that around US\$200 billion worth 
of trade in Africa is carried by the region's trunk road network including strategic trading corridors connecting deep sea-ports to economic hinterlands. These networks include about $10,000 \mathrm{~km}$ of roads. Apart from this, between 60,000 and $100,000 \mathrm{~km}$ of roads are required to provide intra-continental connectivity by way of an intra-regional trunk network. Hence, it can be said that the lack of transport infrastructure is back holding economic integration of Africa. This high cost of infrastructure persists in the continent of Africa, and can have a major impact on regional competitiveness as well as reduce the worldwide competitiveness of the continent's exports and limits the sectors in which African companies compete.

The high cost of infrastructure is present across several sectors, imposing additional costs on businesses and reducing productivity. For example, the poor quality of road, railway and harbor infrastructure generates an additional 30 percent to 40 percent of costs for intra-Africa commodity trading (UN-Habitat, 2014). Nowadays, goods traveling between Lagos (Nigeria) and Accra (Ghana) are frequently transported by sea, despite land proximity between the two cities (OECD, 2018). The port of Lome in Togo, a small West-African nation, has become the leading port in the West African region, while Lagos' port in Nigeria has lost 30 percent of its container traffic since 2015 due to abnormally high costs and notorious congestion (Dynamar, 2018). Regardless, infrastructure services are twice as expensive as elsewhere, reflecting diseconomies of scale in production and high-profit margins due to competition. For instance, the average cost of importing a 20-foot container in Africa is US $\$ 2,793$ with an average delivery time of 38 days. While the average cost of importing a 20-foot container in Singapore is US $\$ 440$ with an average delivery time of 4 days (Bond, 2016). Moreover, poor transport infrastructure accounts for 40 percent of logistics costs in coastal nations and 60 percent in landlocked nations (UN-Habitat, 2014).

In considering barriers against infrastructure and linkages development, the paper also delves into the state of infrastructure in Africa's agricultural production sector. Notably, the region's economy is mostly agrarian, but farmers are unable to move up the value chain without electricity for processing and for preserving produce. As a result, the dearth of infrastructure in Africa has made the continent's domestic market for agricultural production less developed. For instance, local suppliers are not always able to meet demands because electric power is not readily available. Shortages of power and water supplies and inadequate information and communications technology (ICT) infrastructure can reduce productivity by as much as 40 percent (AfDB, 2013). Almost 5 percent of yearly sales are lost due to electrical outages in Sub-Saharan Africa (SSA); the cost of fuel for backup power generation was estimated to be at least USD 5 billion in 2012 (OECD/IEA, 2014); as a result, products are more expensive for consumers.

This is a sector which is frequently seen to have a quintessential enclave activity, solely dedicated to commodity exports and with few externalities to the surrounding economy. With that said, the absence of transport linkages between rural and urban markets lessen opportunities for the evolution of agriculture from subsistence to market-based. The agricultural sector remains largely not modernized although it continues to be the biggest sector in African economies, accounting for 20 percent of regional GDP and 65 percent of employment; this sector has the potential to be much more productive with sustainable energy sources (IEA, 2015).

As for electricity, there are over thirty African nations experiencing power shortages at present and this is leading to either expensive short-term fixes or power blackouts. This has acted as brakes in Africa development. Almost half of Africans (600 million people) did not have access to electricity in 2018, while about 80 percent of SSA firms suffered regular electricity disruptions leading to economic losses (IEA, 2019a). For those that do have electricity access in the region, average residential electricity consumption per capita is equivalent to about half the average level of China or one-fifth of Europe (Bond, 2016).

Most manufacturing activities require reliable access to electricity for several hours a day, at a price that still keeps the activities competitive in the market. For this reason, Africa ambition to accelerate an industrial expansion continues to be hampered in several nations by the unreliable 
Figure 1. Access to Electricity, 2012. Source: Calabrese et a., 2017.

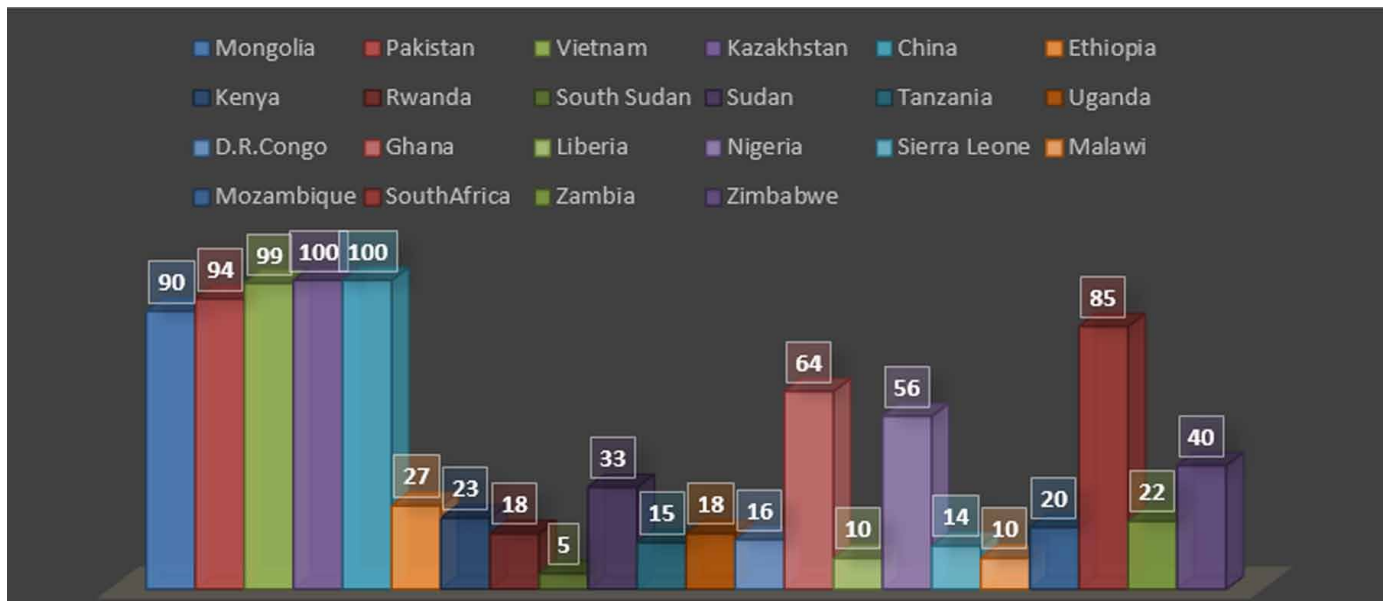

power supply. Only a handful of nations - including Senegal, Ghana, Ethiopia, South Africa, Kenya and Rwanda - are successful in reaching full access to electricity by 2030 . The continent struggles to sustain GDP growth in part is due to the dearth of electricity (Castellano et al., 2015). With that said, figure 1 shows population access to electricity in China and different African economies. While China has a high access rate of 100 percent and Mongolia 90 percent, Africa lags on this indicator, with the highest access rates at 85 percent. Average access to electricity in the West and Southern Africa is at about 35 percent; in Eastern Africa, it is as low as 19 percent (Calabrese et al., 2017). As for regional electricity outages in a month, the study showed that China has a reliable energy supply, with an average of 0.1 outage per months or a bit more than one every year. In comparison, the SSA group rate is in between, with fewer than 3 outages a month on average. What is more, Southern and Eastern Africa suffer from fewer outages (about 5 per month) whereas in West Africa these are more common (over 13 per month on average) (see figure 2).

As for firms that are using generators, the same study shows that the low reliability of the electricity supply is confirmed by the fact that in numerous African economies, companies own generators to minimize disruption in the production process. Notably, 50 percent of firms operating in Africa have generators. Particularly, the number is higher in West Africa (66 percent) and in Eastern Africa (54 percent) compared with Southern Africa (30 percent) (see Figure 3) (Calabrese et al., 2017). Also, in the absence of supply from the formal system, numerous middle-income Africans, desperate for electricity, install high-cost diesel generators. Such generators are polluting and the cost of electricity produced is a multiple of what electricity from the modern sector with technology would cost. Such added costs lessen the competitiveness of African companies. Besides this, in the absence of electricity supply, almost 730 million rely on the traditional use of solid biomass (mainly fuelwood and charcoal) for cooking. Yearly, almost 600,000 premature deaths that occurred in Africa are attributable to household air pollution resulting from traditional use of these solid fuels.

Because of these challenges, Calabrese at al. (2017) study added that SSA electricity price is higher than in China. Only slightly in Eastern Africa (US\$0.16) and considerably in West Africa (US\$0.30) (see figure 3). The authors affirm that Africa prices are not even, nonetheless, while some nations have prices much lower than China's price (Zimbabwe, Mozambique, Zambia, DRC, Sudan, South Africa, and Ethiopia), some others have very high energy prices (especially Sierra Leone), driving the average value up.

As such, based on the International Energy Agency (IEA) outlook, SSA electricity demand is anticipated to triple by 2040, to reach 1.300 terawatts per hour (TWh). Also, by 2040, total power 
Figure 2. Electrical outages in a month, various years. Source: Calabrese et a., 2017.

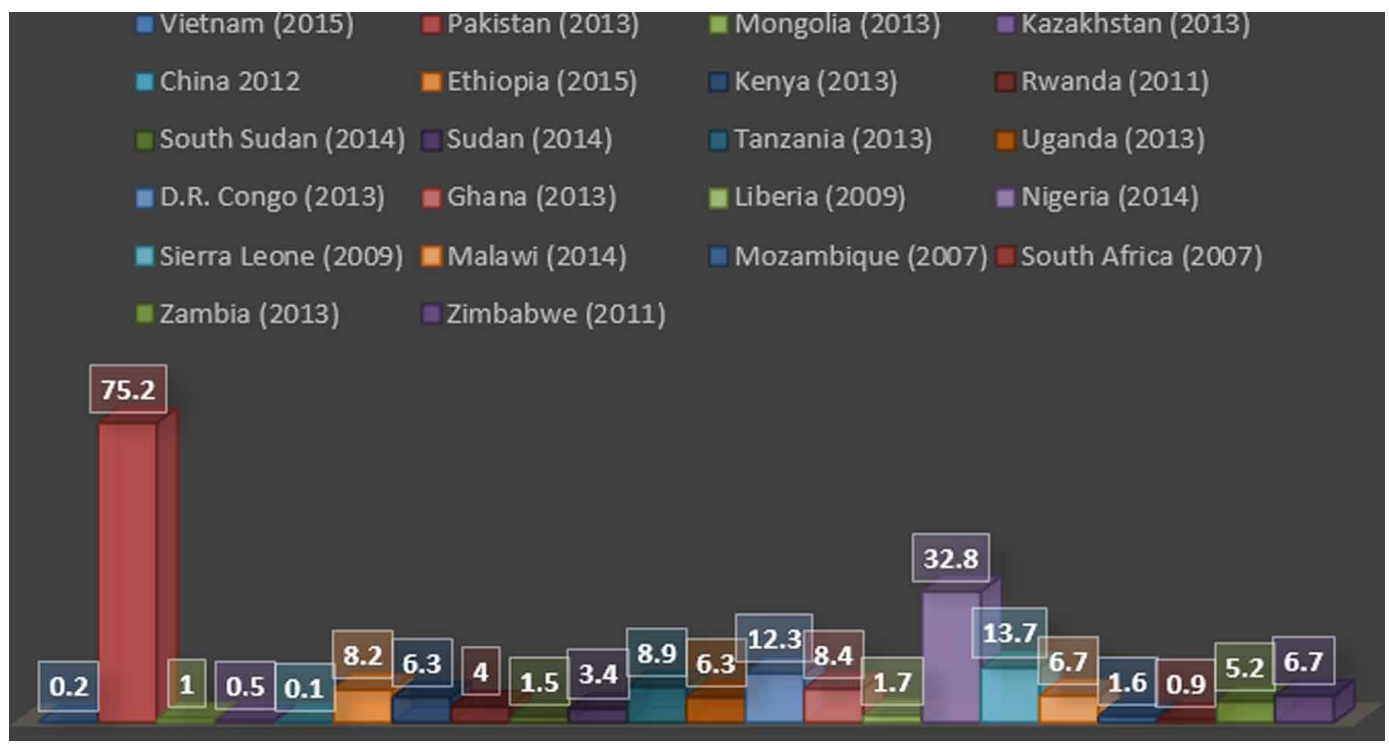

Figure 3. Price of Electricity, various years. Source: Calabrese et a., 2017.

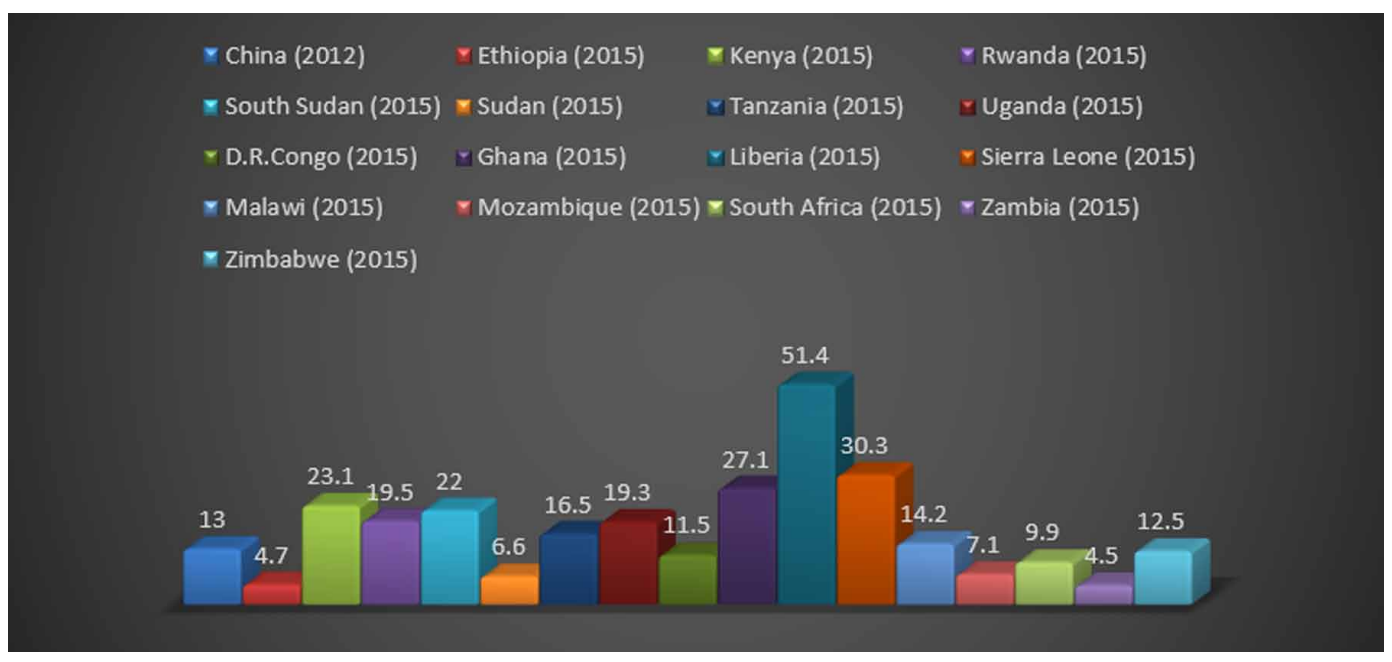

generation capacity is anticipated to quadruple to 385 Gigawatts. The report added that by 2040 , demand for the industry will double while residential demand will grow by over five times of current levels. By 2040, at a rate of 6 percent per year, electricity demand growth will surpass GDP growth (IEA, 2014). Africa has ample primary energy resources to meet the infrastructure demand mentioned initially: recoverable oil resources will be sufficient for next 100 years, coal for other 400 years and gas for over 600 years, and renewable energy sources (geothermal, hydro, wind, and solar) are abundant (IEA, 2014).

With that said, Figure 4 shows that the proportion of SSA's population having access to piped water, electricity, flush toilets and landline telephony is considerably higher in urban areas than in 
rural areas. Progress in the provision of social infrastructure has at best been slow, and more typically non-existent. This contrasts with other low-income economies in which there has frequently been substantial headway in infrastructure provision. For instance, SSA has three times more generating capacity per capita in 1970 than India, but by 2000 India had surpassed SSA and had twice as much per capita capacity as SSA (Foster et al., 2008). Therefore, beyond the poor availability of infrastructure is the slow rate of headway (see figure 5 ).

On the positive side, Lomas (2012) asserts that mobile phone networks have expanded speedily in the continent reaching 80 percent of the population, from 2 percent in 2000 . Africa as a whole recorded the largest leap in cellular signal coverage from nearly 23 percent of the population in 2003 to 88 percent in 2012 (The African Capacity Building Foundation, 2016).

The continent has also developed new services, such as M-Pesa mobile money transfer -pioneered in East Africa -on its network platform (AfDB, OECD, and UNDP, 2014; Shapshak, 2018). Simply

Figure 4. The rural-urban divide in Africa's infrastructure. Source: Derived from Foster et al. 2008 and cited in NEPAD, 2015.

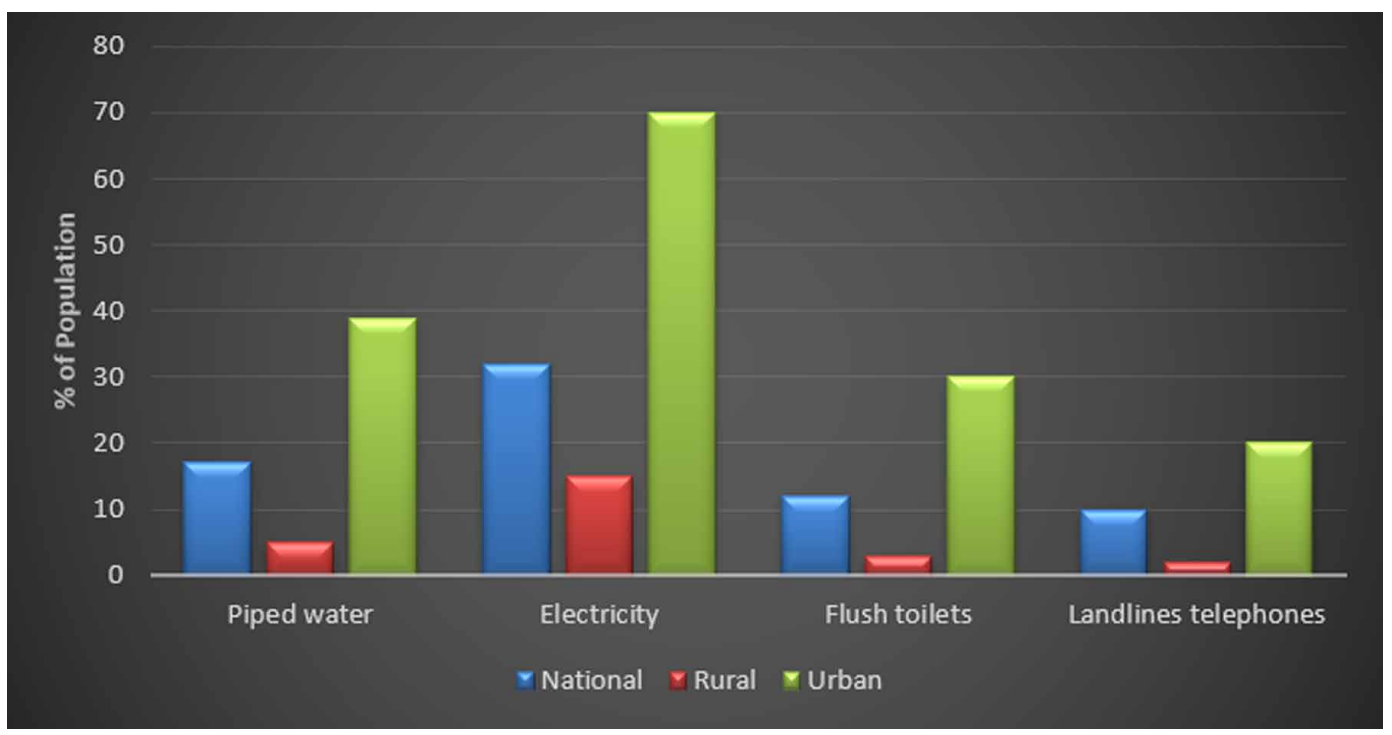

Figure 5. Slow progress in infrastructural development in Africa. Source: Derived from Foster et al, 2008 and cited in Source: NEPAD, 2015.

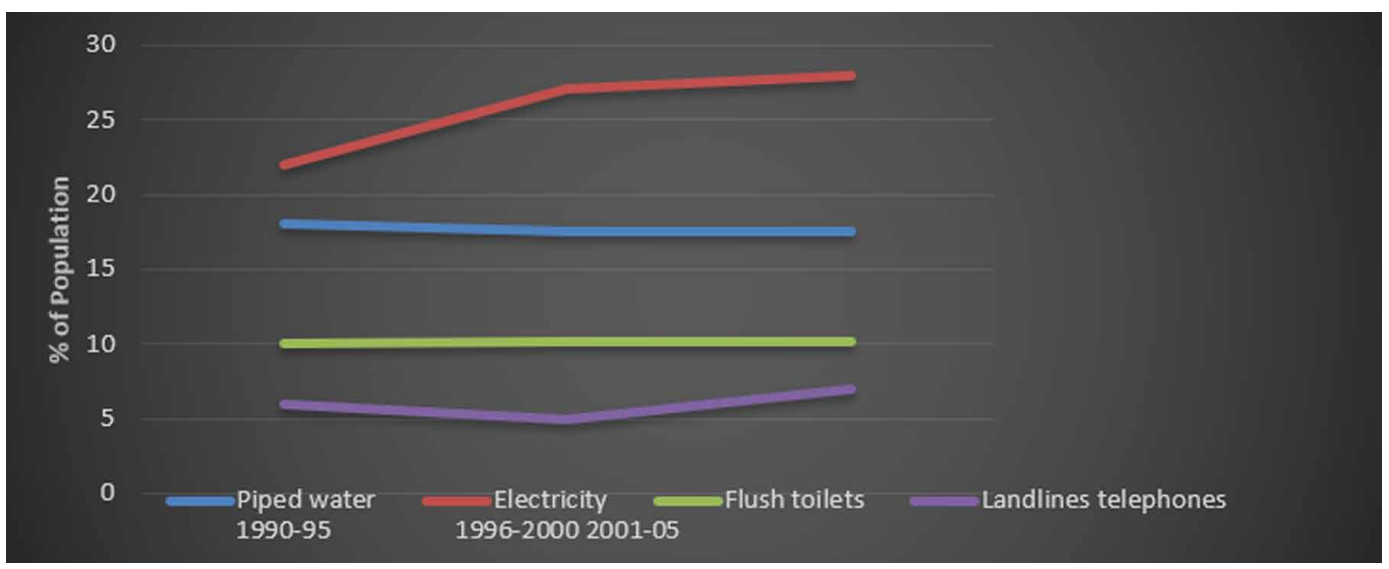


gaining access to M-Pesa mobile-money service, 2 percent of Kenya households were lifted out of poverty between 2008 and 2014 (Tompsett, 2018). According to the World Bank Global Findex Database, "the power of financial technology to expand access to and use of accounts is demonstrated most persuasively in SSA." This was mentioned during the bank's financial inclusion survey which discovered 21 percent of adults in the region presently have a mobile money account (World Bank, 2017a). This is "almost twice the share in 2014 and easily the highest of any region globally." See table 2 for a summary of some data regarding regional rural access to the mobile cellular link. In general, the astute adoption of novel technology allows poorly endowed nations due to the capability to leapfrog older technologies prevalent in more developed nations; mobile phones are one best instance of this phenomenon.

Table 2. Rural access to mobile cellular link

\begin{tabular}{|c|c|c|c|c|}
\hline Region & $\begin{array}{c}\text { General mobile cellular } \\
\text { coverage (\%) }\end{array}$ & $\begin{array}{c}\text { Rural population } \\
\text { coverage (\%) }\end{array}$ & $\begin{array}{c}\text { Rural population } \\
\text { covered (millions) }\end{array}$ & $\begin{array}{c}\text { Rural population } \\
\text { not covered } \\
\text { (millions) }\end{array}$ \\
\hline Africa & 88 & 79 & 498 & 129 \\
\hline Americas & 99 & 96 & 171 & 9 \\
\hline Asia & 92 & 87 & 2,017 & 309 \\
\hline Europe & 100 & 98 & 3 & 0.6 \\
\hline Oceania & 98 & 84 & 2,886 & 451 \\
\hline World & 93 & 87 & & 3 \\
\hline
\end{tabular}

Source: The African Capacity Building Foundation, 2016

For transport, high transport cost adds 75 percent to the price of the product in the region. As for the nation, for instance, improving Kenya's infrastructure up to the level of middle-income nations, would bolster annual growth by over 3 percent points and for Nigeria, this would mean an upsurge in yearly real GDP growth by almost 4 percentage points. ${ }^{7}$ Closing the infrastructure quantity and quality gap relative to the best performers in the world could raise the growth GDP per capita by 2.6 percent per year (World Bank, 2017b).

More so, figure 6 highlights the effect of utilization losses in electricity, water, and transport on GDP for the most affected low-and middle-income nations, including 21 African nations. African nations comprise at least half of the top 15 most-affected nations in each category of infrastructure disruption. Speaking of infrastructure disruption, it affects firms through various impacts (see Table 3 ) and costs firms over US $\$ 300$ billion per year (Hallegatte et al. 2019). Most visible are the direct impact; a firm relying on water to cool a machine must halt production during dryout; a restaurant with an electric stove cannot cook meals without power. Disruptions leave production capacity unused, reduce firms' sales, and delay the supply and delivery of goods. As such, the largest potential growth benefits that the continent of Africa envisaged would come from closing the gap in electricitygenerating capacity, water, transport and most especially from infrastructure disruption.

To close the continent infrastructure gap, new estimates by the African Development Bank (AfDB) suggest that Africa's infrastructure requires US\$130-170 billion yearly, with a financing gap in the range of US\$67.6-US\$107.5 billion (AfDB, 2018) per year; higher than the most widely quoted figure on Africa's infrastructure needs of US\$93 billion, from 2006 Africa infrastructure Country Diagnostic (ACID) study (quoted in Foster and Briceño-Garmendia, 2010). To make the matter more difficult, sluggish economic growth has put constraints on African government budgets while the Basel III rules ${ }^{8}$ make it harder for banks to free up capital for infrastructure lending. 
Figure 6. Top 15 nations with greatest utilization rate losses, by type of infrastructure disruption

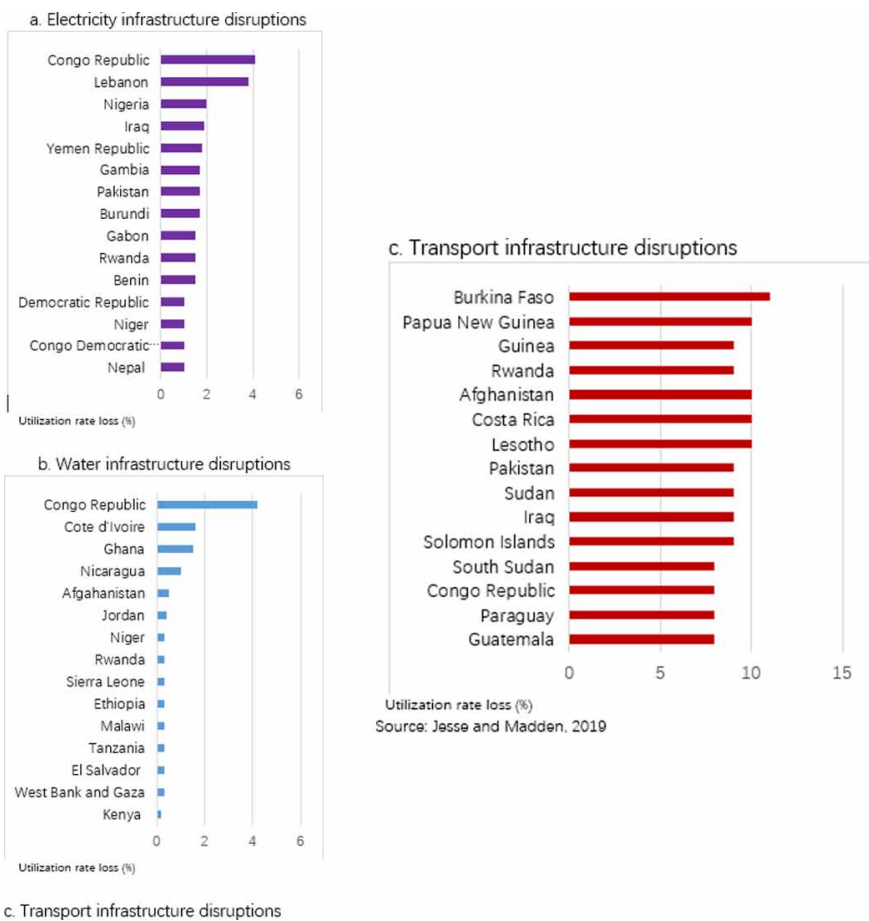

Table 3. Disrupted infrastructure services have multiple impacts on firms

\begin{tabular}{|c|c|c|c|}
\hline Sector & Direct impacts & Coping costs & Indirect impacts \\
\hline Power & $\begin{array}{l}\text { Reduced utilization rates } \\
\text { (US } \$ 38 \text { billion a year) } \\
\text { Sales losses (US } \$ 82 \text { billion } \\
\text { a year) }\end{array}$ & $\begin{array}{l}\text { Generator investment } \\
\text { (US\$6 billion a year) } \\
\text { Generator operation } \\
\text { costs (US } \$ 59 \text { billion a } \\
\text { year) }\end{array}$ & $\begin{array}{l}\text { Higher barriers to } \\
\text { market entry and lower } \\
\text { investment }\end{array}$ \\
\hline Water & $\begin{array}{l}\text { Reduced utilization rates } \\
\text { (US\$6 billion a year) } \\
\text { Sales losses }\end{array}$ & $\begin{array}{l}\text { Investment in } \\
\text { alternative water sources } \\
\text { (reservoirs, wells) }\end{array}$ & $\begin{array}{l}\text { Less competition and } \\
\text { innovation due to lack of } \\
\text { small and new firms }\end{array}$ \\
\hline Transport & $\begin{array}{l}\text { Reduced utilization rates } \\
\text { (US\$107 billion a year) } \\
\text { Sales losses } \\
\text { Delayed supplies and } \\
\text { deliveries }\end{array}$ & $\begin{array}{l}\text { Increased inventory } \\
\text { More expensive } \\
\text { location choices for } \\
\text { instance, in proximity to } \\
\text { clients or ports }\end{array}$ & $\begin{array}{l}\text { Inability to provide } \\
\text { on-demand services and } \\
\text { goods } \\
\text { Diminished } \\
\text { competitiveness in } \\
\text { international markets }\end{array}$ \\
\hline Telecommunications & $\begin{array}{c}\text { Reduced utilization rates } \\
\text { Sales losses }\end{array}$ & $\begin{array}{l}\text { Expensive location } \\
\text { choices close to fast } \\
\text { internet }\end{array}$ & \\
\hline
\end{tabular}

Source: Hallegatte et al. 2019

Note: Highlighted in bold are the impacts for which original estimates are presented in this section. Estimates cover low-and middle-income nations 
As such, African nations are presently looking for financial resources well beyond their own domestic revenues and foreign aid, and its willingness to take out Chinese loans to plug the financing gap. The Africa infrastructure gap and financing is also broadly acknowledged by individual governments, African regional organizations, such as NEPAD ${ }^{9}$, the East African Community ${ }^{10}$, $\mathrm{SADC}^{11}$, and ECOWAS ${ }^{12}$, by United Nations agencies (particularly the UNECA ${ }^{13}$ ), by Development Banks (such as the African Development Bank ${ }^{14}$ ), the International Financial Institutions (particularly the World Bank) and the Organization for Economic Co-operation and Development (OECD), Development Assistance Committee (DAC) as well as individual bilateral donors. Although Africa's financing may not be met solely by Chinese financing, China's role is seen by many as important. With that said, it is in this context of investment and weak infrastructural provision in Africa, the author tries to identify forward and backward linkages in Chinese infrastructure investment in Africa.

\section{IDENTIFICATION OF FORWARD AND BACKWARD LINKAGES AND ANALYSIS OF CASES}

Infrastructure development is critical to the continent of Africa economic development and poverty reduction. That is why presently, it is infrastructure African nations need most and infrastructure is what China is most equipped to offer. It is not lost on several African leaders that hardly four decades ago China was in the same position the continent of Africa is today - a backwater nation whose economy made up hardly two percent of worldwide GDP. However, over the past few decades, China shocked the world in the way that it used infrastructure to propel economic growth, creating a high-speed rail network that presently top 29, 000 kilometers, paving over 100, 000 kilometers of novel expressways, constructing over 100 novel airports, and constructing no less than 3,500 novel urban areas - which comprise 500 economic developmental zones and 1,000 city-level developments (Wade, 2019). Over this period, China's GDP has grown more than 10-fold, ranking number two globally nowadays.

Therefore, China and Africa regard infrastructure development as crucial for development of the continent of Africa, especially since infrastructure development played a major role in China's own poverty alleviation as well as economic transformation. China's approach to infrastructure development in a fundamentally dissimilar way from its counterparts in the West both home and overseas. China's approach is relational and fits the recent African Union Agenda 2063 vision; as such, numerous African governments are looking to China to bring their experience to their nations; no wonder rather than foreign aid, Chinese companies have brought employment, training, novel technology and financing (Reuben, 2018), and supporting Africa to develop the continent's infrastructure sector (see table 4 and figure 7). Figure 7 shows that most financed projects are in transport, shipping and port sectors (52.8 percent), followed by energy and power (17.6 percent), real estate (14.3 percent), including industrial, commercial and residential real estate) and mining sectors ( 7.7 percent).

As displayed in figure 7, investment in infrastructure and capital projects can be essential to diversify economies and promote private sector activities and industrialization, ensuring enough jobs are created for 12 million young inhabitants entering Africa's workforce each year (Deliotte, 2018). With that said, economic literature identifies the significance of China's infrastructure investment as one of the key catalysts behind development in the region (Godfrey and Ross, 2016). China's emphasis on Africa's infrastructure construction intensified with the launching of the Belt and Road Initiative (BRI). As a result, in contrast to several traditional donor nations centering on social sectors, China's lending agencies offer significant loans for infrastructure projects in Africa (Chen and Nord, 2018).

Chinese loans have assisted to finance large-scale investments in infrastructure, energy and mining, thereby closing the continent critical infrastructure deficit, creating economic stimuli with a large positive effect on growth and prosperity (Kuo, 2018). Based on the Deloitte report, thus far, by 2018, China-Africa Development Fund (CADFund) had invested over US\$4.6 billion in more than 90 projects in 36 African nations. The report added that overall, China has partaken in more than 200 African infrastructure project, making China the single largest financier of African 
Figure 7. African investment in infrastructure and capital projects by financing source. Source: Deloitte, 2018 Note: EU Nations include Austria, Belgium, France, Germany, Italy, Luxembourg, Norway and Portugal. Single Nations include Angola, Brazil, Ghana, India, Japan, Macau, Mauritius, Morocco, Nigeria, Russia, South Korea, Switzerland and Thailand.

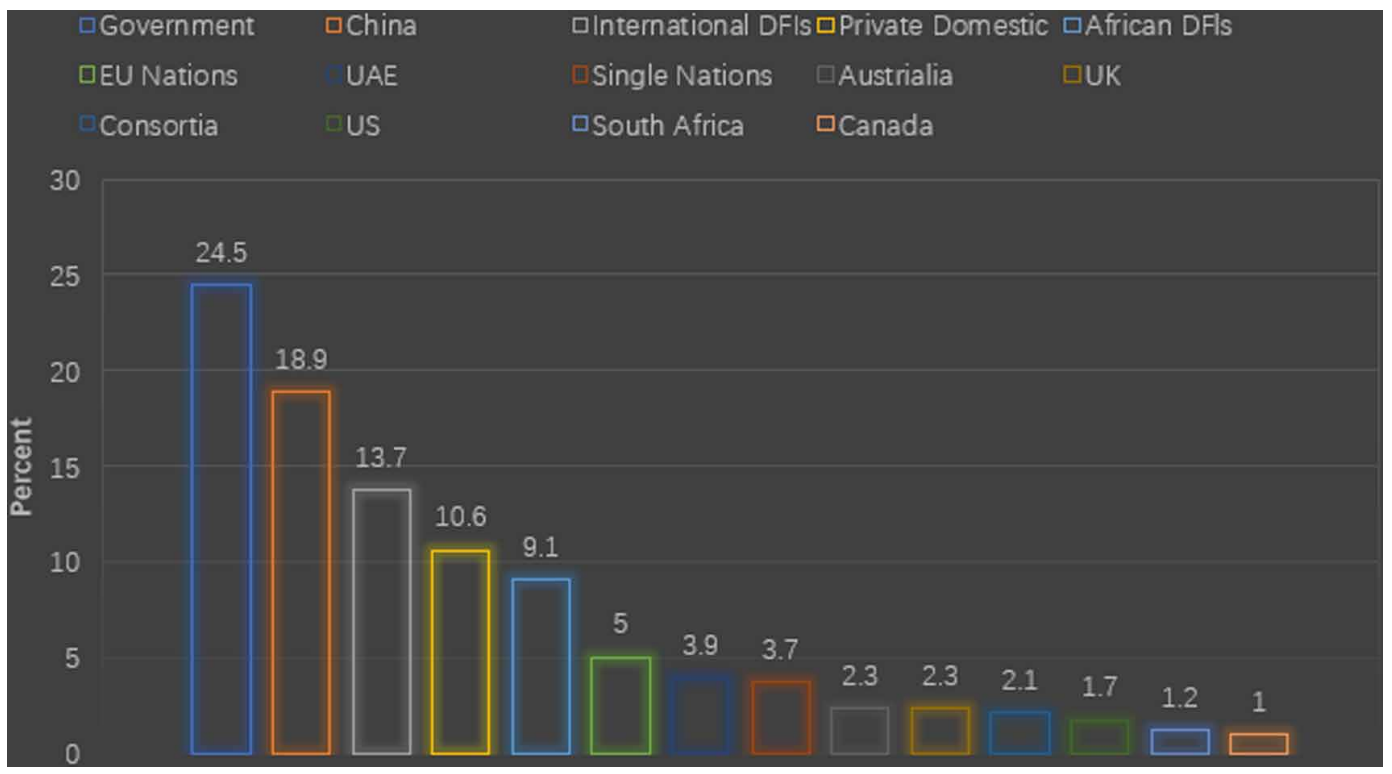

infrastructure,${ }^{15}$ financing one in five projects and constructing one in three (figure 8) ${ }^{16}$ In addition, Chinese firms have completed and are building projects that are designed to assist add to or upgrade nearly $30,000 \mathrm{~km}$ of highways, $2,000 \mathrm{~km}$ of railways, 85 million tonnes per year of port throughput capacity, over nine million tonnes per day of clean water treatment capacity, nearly $20,000 \mathrm{MW}$ of power generation capacity, and over $30,000 \mathrm{~km}$ of transmission and transformation lines (Deloitte, 2019). The Deloitte report affirms that the various projects are anticipated to boost local exports by US $\$ 5.8$ billion and create the local tax revenue of US $\$ 1$ billion.

Not to mention the influence via spillover effects of construction projects, such as significant exports of machinery and transport equipment and labor exports (workers on contracted projects and workers doing labor services). Notably, looking at China's footprint in Africa's infrastructure development path, it is in this context the author analyses the forward and backward linkages of different infrastructure cases that China has invested in so far.

Table 4. Trends in infrastructure finance in Africa, by source (\$billion)

\begin{tabular}{|c|c|c|c|c|c|c|}
\hline Source & $\mathbf{2 0 1 2}$ & $\mathbf{2 0 1 3}$ & $\mathbf{2 0 1 4}$ & $\mathbf{2 0 1 5}$ & $\mathbf{2 0 1 6}$ & Average \\
\hline African governments & 26.3 & 30.5 & 43.6 & 24 & 26.3 & 30.1 \\
\hline Donors (ICA members) & 18.7 & 25.3 & 18.8 & 19.8 & 18.6 & 20.2 \\
\hline MDBs and other bilateral & 1.7 & 2 & 3.5 & 2.4 & 3.1 & 2.5 \\
\hline China & 13.7 & 13.4 & 3.1 & 20.9 & 6.4 & 11.5 \\
\hline Arab nations & 5.2 & 3.3 & 3.4 & 4.4 & 5.5 & 4.4 \\
\hline Private sector & 9.5 & 8.8 & 2.9 & 7.4 & 2.6 & 6.2 \\
\hline Total & 75.1 & 83.3 & 75.4 & 78.9 & 62.5 & 75.0 \\
\hline
\end{tabular}

Source: AfDB, 2018 
Figure 8. China's share of regional and continental project activity. Source: Deloitte, 2018.

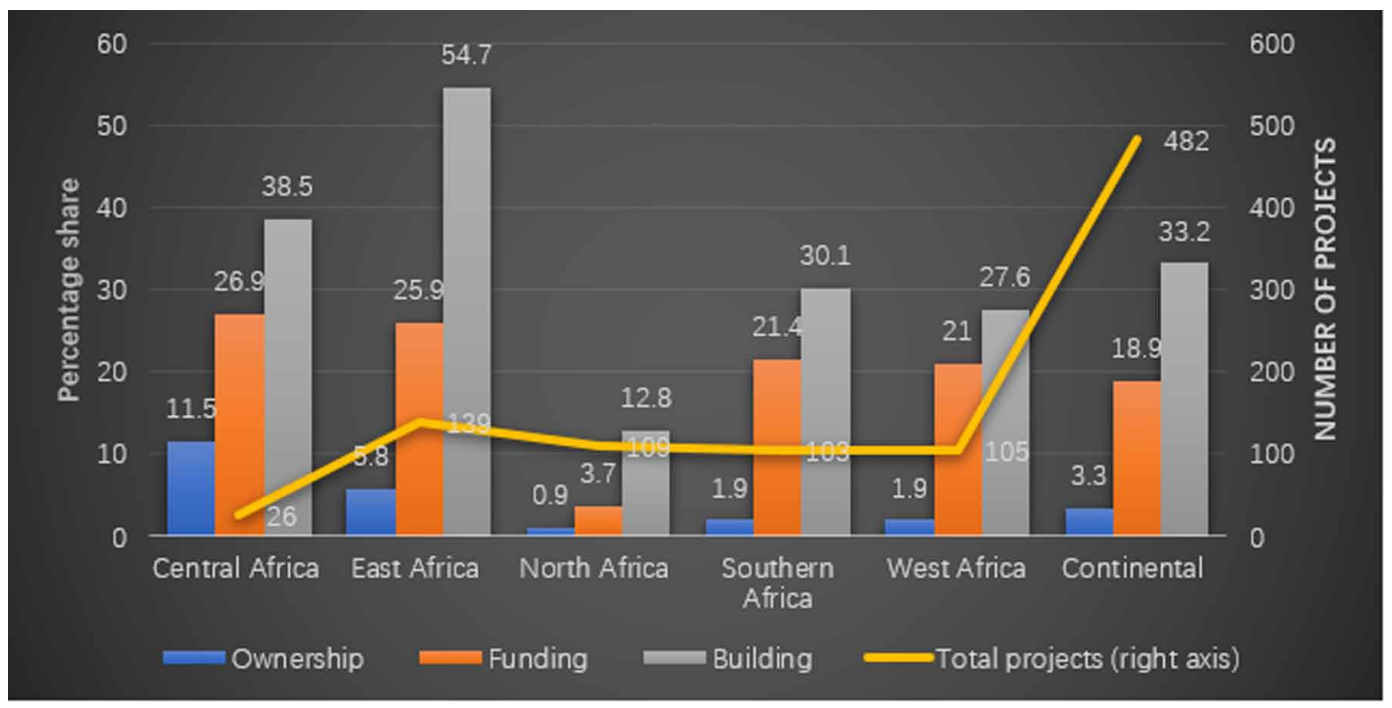

\section{Analysis of Cases}

\section{Case 1: Tanzania-Zambia Railway}

Behind the seemingly bleak outlook, there is a silver lining in terms of diversity in some other African nations keen to invest heavily in infrastructure projects to boost growth, often with China's involvement. Therefore, the Chinese government has shown remarkable prowess in investing in Africa's infrastructure sector. Chinese involvement is traceable back to the 1960s, when talks opened with Tanzania and Zambia to an ambitious post-colonial railway from Dar es Salaam to Kapiri Mposhi, just north of Zambia's capital, Lusaka. The Tanzania-Zambia Railway also known as Tanzania Zambia Railway Authority (TAZARA) is a binational rail network, extending 1,860km, with 975km in Tanzania and $885 \mathrm{~km}$ in Zambia (see table 8), and the network is based on the Cape Gauge with a width of 1,067 mm, built between 1970 and 1975 (Brautigam, 2009; Atsushi et al., 2017). The TAZARA railway is generally regarded as China's first large-scale venture financed by Chinese loan during the Mao era, for which China provided a zero-interest loan of $\$ 570$ million, more than all other Chinese-sponsored overseas projects combined prior to 1975 (Donghai, 2016). The purpose of the railway project is to end landlocked Zambia's dependence on Rhodesia (Zimbabwe) and South Africa by giving the nation an alternative option for coastal access (Monson, 2013:47).

\section{Table 5. Tanzania: Rail networks (km)}

\begin{tabular}{|c|c|c|c|}
\hline Tanzania Railways Limited (TRL) & $\mathbf{2 , 5 8 2}$ & TAZARA & $\mathbf{1 , 8 6 0}$ \\
\hline Central line & 1,254 & Tanzania & 975 \\
\hline Tanga Line & 437 & Zambia & 885 \\
\hline Link Line & 188 & & \\
\hline Mwanza Line & 378 & & \\
\hline Mpanda Line & 210 & & \\
\hline Singida Line & 115 & & \\
\hline
\end{tabular}

Source: Atsushi et al., 2017 
The scale and the cost of the project and the commitment shown by the Chinese in delivering it on time in the face of the refusal of the funding of the project by Western nations and the World Bank is often pointed to by the Chinese as a symbol of their friendship with and commitment to Africa. It should be noted in passing that this was the period of the Cold War, and that perhaps the Western unwillingness to finance the project could be because they viewed the project through the Cold War lens. To build the Tazara railway, the Chinese needed to bore ten kilometers of tunnels and construct 300 bridges, which required shiploads of materials and equipment. It also involved dozens of Chinese ministries, which did put enormous pressure on Chinese aid (Brautigam, 2009). At completion, 89 million cubic meters of earth and rocks had been moved, 320 bridges, 22 tunnels and 225 culverts built (Xinhuanet, 2019). Xonstruction of the railway served as a blueprint for future large-scale Chinese projects in Africa. With that said, the most significant for Africa as well as the outside world is to know if these sorts of projects have created backward and forward linkages. Based on this instance several of these can be examined.

Researchers who study the issue of skills-transfer from Chinese construction companies identify that, as early as the 1970s, during the construction of the Tazara railway, "African and Chinese workers not only labored side by side but also engaged in what was known as "technical cooperation", as Chinese railway experts trained their African counterparts in the workplace and technical training shops" ${ }^{17}$. Specifically, Brautigam affirms that 16,000 skilled Chinese workers were employed and tens of thousands of Africans workers (Brautigam, 2009). Another study also found that Chinese construction companies provide employees with on-the-job training, focusing particularly on machine operation. ${ }^{18}$ These contributions and benefits from building the Tazara railway regarding employment opportunities and skill transfer show that forward linkages for increasing labor are skills these workers learnt and gain, which they may take into other firms or use to set up their own firms in future.

Alternatively, this could also be seen as a backward linkage because in order to build and improve the railway the project will need workers and so people turn out to be an essential factor for development of the project. While creating employment opportunities and transferring skills to the people is not only an investment for the project, it is also beneficial for the future of the host economy.

With respect to labor, training centers and engineering workshops have emerged as a way of preparing and raising knowledge to novel workers about this certain kind of industry but also a way of training people and giving them access to skills and knowledge that serves the industry needs as well as practical skills and experience that are needed to work and meet construction firm interests. Also, these investments can be referred to as backward linkages as investing in railway, directly led to growth in training centers, this implies that the construction firm is directly investing in human capital.

With that said, over the past four decades, Tazara has been playing a vital role in economic and social development of Tanzania and Zambia. indicating that there was a great need for the Tazara facility. This is because, from the environmental perspective, the study shows that the railway has an important advantage to foster sustainable transportation (Kopp et al., 2013). Also, the rail sector accounts for only 3.6 percent of total transport emissions, while it contributes to more than 8 percent of the total movements of passengers and goods over the world (IEA and UIC, 2015; Atsushi et al., 2017). Rail carries 6.3 percent of the global passenger transport demand and 9 percent of total freight demand (see table 9). Therefore, it was a good ideal for both Tanzania and Zambia governments to build the Tazara railway. For instance, Zambia is a landlocked nation as stated initially, to survive economically, the nation must import food, raw materials and mining equipment. Likewise, the nation must export commodities such as copper which accounts for 90 percent of the nation's export earnings.

The railway was needed to reduced freight rates for transporting copper from Mbeya to Dases-Salaam, stimulate agricultural and livestock development in the region and upsurge Zambia and Tanzania opportunities for external trade. For instance, nearly 31 miles (50 kilometers) from the Zambian borders lies the Tanzania town of Mbeya. The plateau and hill nation surrounding Mbeya hold considerable potential for cultivation of grain, oilseed and other goods. About midway through Tanzania is the Kilombero's Valley, which even presently is Tanzania's major source of sugarcane. 
Table 6. Global transport modal share (\%), 2012

\begin{tabular}{|l|c|c|c|}
\hline & Passenger (passenger-km) & Freight (ton-km) & Total (Transport unit) \\
\hline Road & 82.7 & 8.8 & 31.3 \\
\hline Aviation & 10.6 & 0.7 & 3.7 \\
\hline Navigation & 0.3 & 81.5 & 56.8 \\
\hline Rail & 6.3 & 9.0 & 8.2 \\
\hline
\end{tabular}

Source: IEA and UIC, 2015; Atsushi et al., 2017

Kilombero's well-watered, fertile soil holds great potential. Besides sugarcane, it is suitable for growing rice and vegetable and for raising livestock. With the railway providing easy transportation from the port city of Das-es-Salaam to Mbeya and New Mposhi in Zambia and other diverse villages, it was a good reason to set up agricultural production, and this has made trade within the region much easier. Backward linkages include farmers' purchase of farm production items (seed, fertilizer, chemicals, etc.), while forward linkages include the processing of farm products, and the transportation of those processed products. This has externalities for other nations in the region has the infrastructure is also available for other neighboring nations such as Malawi and Southern Democratic Republic of Congo, which are practically landlocked in the region.

The nature of infrastructure has an important implication for development of linkages. Some infrastructure is highly specific to a commodity producer, and has very low potential for positive spillovers which might facilitate the growth of backward, forward, or horizontal linkages. For example, the Tazara railway line between Zambia's landlocked copperbelt and the port of Dar es Salaam in Tanzania, the infrastructure has the capacity to meet the needs of multiple users, both feeding into and out of copper mines, and feeding into and out of other sectors of the economy. No wonder Zambia was able to export its copper to Europe through Tanzania without using the railway built by Britain and controlled by then white-ruled South Africa,

Monson (2009) affirms that the Tazara railway facilitated trade within the region for vital perishable and non-perishable goods. The railway line was able to reduce the distance for communication and enables firms to take advantage of novel business opportunities and create forward linkage. Monson added that the Tazara railway led to economic development in other parts of the East African region and other sectors such as the hydroelectric power plant at Kidatu and the paper mill at Rufiji (Monson, 2009). This is another good example of backward linkage created from constructing the Tazara railway. Likewise, it can be a forward linkage since the power plant generates electric power for the train to run.

Although the Tazara railway has produced a lot of positive advantages, it has had numerous problems since its completion, especially the dearth of the required technical maintenance, upgrade, and ineffective operation and management. Sun affirms that China has complained that the governments of Tanzania and Zambia only "manage" but never invest in the Tazara Railway, and the Western management system they adopted has prevented Chinese involvement in the key management issues to improve its performance. Sun added that the problems caused during the operation process have been blamed on the quality of Chinese construction, which has tarnished the image of Chinese projects in Africa (Sun, 2017).

Having learned these lessons from the Tazara Railway, China is determined to obtain management rights for both the Mombasa-Nairobi and Addis-Djibouti lines. Ehizuelen (2017) affirms that the Addis-Djibouti line adopts the " $6+2$ model", in which China Road and Bridge Corporation (CRCC) and China Railway Group (CRG) will operate and maintain the railway for six years upon the launch of operation and provide two additional years of technical support during the gradual handover of management authorities. He added that in the same way, CRBC has reached a 10-year agreement 
under a " $5+5$ model" with Kenya Railways Corporation taking over the operation and maintenance of the Mombasa-Nairobi line, including the train dispatch system, maintenance of railways, and the locomotives (Ehizuelen, 2017). The " $5+5$ model" means that the Kenyan side will conduct a performance evaluation of the service by CRBC by the fifth year.

In both cases, China claims that it is training a significant number of local technical employees and providing technical transfer under the framework of capacity building. This is an important sustainability issue that African policymakers and leaders should seriously consider when it comes to such huge undertakings in Africa in the future, not only in partnership with the Chinese but also with other foreign governments and firms.

\section{Case 2: Mombasa-Nairobi Standard Gauge Railway}

One of Kenya's top developmental challenges continues to be the shortage of physical infrastructure. Greater economic activity, enhanced efficiency and increased competitiveness are hampered by inadequate transport, communication, water and power infrastructure. The world is eager to do business with Kenya, but finds it hard to access Kenyan markets, especially in the interior, because of poor infrastructure. Physical infrastructure covering transportation, power and communication via its backward and forward linkages facilities growth; while social infrastructure including water supply, sanitation, sewage disposal, education and health, which are primary services, has a direct impact on the quality of life. Without this infrastructure, Kenya will not attain the growth levels anticipated or needed. As such, infrastructure planning and investment are, therefore, critical if Kenya's massive economic and developmental potential is to be realized.

With that said, Infrastructure projects bring symbolic benefits as well, highlighting the nation's independence and self-determination. This is particularly true for rail projects, which often replace colonial-era lines that were used to move resources out of Africa, before falling into disrepair. As such, the replacement of the old, colonial-era narrow gauge track with the 472 kilometers Mombasa-Nairobi standard-gauge line worth US\$3.8 billion ${ }^{19}$ is the transport solution and experience that has been missing since the Kenya-Uganda railway over a century ago opened up East Africa by stimulating the growth of businesses and trading centers along the Northern Corridor transport system, and will raise the speed of trains on the line, from $30 \mathrm{kph}$ to $90 \mathrm{kph}^{20}$. The Mombasa-Nairobi Standard Gauge Railway (SGR) built by China Road and Bridge Corporation and financed largely by Chinese credit lines, closing a 110-year chapter of reliance on colonial infrastructure was inaugurated on May 31, 2017.

According to the Kenya National Bureau of Statistics (KNBS), the fast developing economy of Kenya that is highly dependent on agriculture, trade and tourism (KNBS, 2019) needed an efficient railway especially connecting Mombasa, the main port to upcountry. The railway will definitely reduce traffic on the notorious Mombasa road by a big margin. In the early stages of its implementation, the mega infrastructure was perceived as any other grand public investment that would add to the stock of infrastructure and improve transportation, ease the cost of doing business for the private sector, permits consumption of cheap foreign goods, and enables enterprises to export locally manufactured coffee, tea, and leather with lower cost. The railway not only transform people's lives, but also witnessed the development of Africa-China cooperation. As such, some commentators consider China's "railway diplomacy" as a boon for Africa (Pham et al. 2018).

Morlin-Yron (2017) asserts that in Africa where, 90 percent of all African imports and exports are conducted by sea through ports and specifically Kenya, where almost 4,000 trucks travel every day from Mombasa to Nairobi, the railway becomes very advantageous allowing goods to flow easily from ports inland. Initially, for traveling between these two biggest cities, Kenyans either took very expensive flights (USD 150-200 round trip) or opted for a 12-hour long road trip (Wu et al, 2019). The SGR was proposed was able to remedy these hindrances and shortened passenger travel time to a little more than four hours and freight transportation to less than eight hours (Global Railway Review, 2017). The Mombasa-Nairobi SGR has established backward and forward linkages with the economy by facilitating the seamless movement of bulk cargo, already ferried two million passengers, 
significantly increasing local business, improved tourism opportunities to Kenyan hinterland and across the borders. The SGR pulls along the manufacturing sector and stimulates domestic and international trade, thereby positioning it as a regional logistics hub.

Notably, manufacturing, one of President Uhuru's 'Big 4' (food security, affordable housing, manufacturing, and affordable healthcare for all) pillars of development in his second and final five-year term, will be the greatest beneficiary of the SGR. The SGR links the planned Naivasha Export Processing Zone (EPZ) and OI Karia geothermal fields to the Nairobi-Mombasa railway. Therefore, Kenya's upcoming export-driven manufacturing and processing industry will not only take advantage of competitively priced geothermal electricity but also benefit from direct transportation to the Mombasa port for export. As a result, the modern railway system, which has been glorified and vilified in equal measure, will be serving as a novel engine of Kenya's economic growth and makes the entire eastern region more dynamic entrenching itself as the nerve center of shared industrial growth and economic prosperity for the region.

China supporting Africa to build railways is a way of joining the dots in Africa and forming lines; lines that are cross-continental and will potentially change earlier trade and investment trends laid down by the colonialists. The SGR is part of China's novel "Belt and Road Initiative" and aim to open East and Central Africa up to international trade and investment. Improving connecting is vital for promoting the continent's goods and commodity exports, which can thereby assist African nations to integrate more fully into global value chains. According to the World Bank report, a 1 percent decrease in trade costs is likely to raise bilateral trade between economies that participate in BRI projects by 1.3 percent (Chen and Lin, 2018). The authors added that the initial estimates propose that the BRI transportation networks could bolster FDI on the continent by 7.4 percent, with the largest impact on GDP growth in Sub-Saharan Africa region (Chen and Lin, 2018).

Therefore, improvement in the network and capacity of railways and other cross-border transport infrastructure could lead to significant economic benefits eventually, boosting more intra-African trade as well as augmented investment, the related technology and skill transfers, creating employment and higher growth in African economies. These would be a boon on the continent, where endemic poverty has contributed to insecurity and instability as well as a prominent reminder of China's presence in Africa. On the other hand, this would imply that forward and backward linkages would be created as the building, roads, and seaports would need a great amount of labor, As a result, the SGR project had created over 46,000 local jobs (Mutethya, 2018). The quality of life of these workers who contribute to the building of the railways, roads and seaports will improve and this can affect the entire economy of the nation positively. Likewise, the SGR project brought about 2,071 Chinese workers, mainly in management and engineering (Kenya and Economic and Trade Association, 2017).

One of the most vital elements of the contract signed by the Kenya government and CRBC was the emphasis it placed on training. At the beginning of the Mombasa-Nairobi SGR project, CRBC set up a three-pronged training program for Kenyan railway experts (Wu et al.,2019). The three focus areas included on the job training for local employees in the construction stage, training for railway engineering personnel in the operation stage, and promoting joint education programs in related majors between Chinese and Kenyan universities respectively. CRBC also worked in cooperation with the Kenyan government to sponsor 60 Kenyan high-school graduates to study at prestigious universities in China (four years in English or five years in Chinese) in railway-related majors (Kenya China Economic and Trade, 2017). The first group of 25 Kenyans took up the course in 2016 and another 35 enrolled in 2017 (Mutethya, 2018). At least 2,000 youth are set to be trained in the operation and maintenance of the SGR, according to the transport secretary of Kenya (Business Daily, 2017).

Besides training programs, CRBC launched a railway technology transfer training center at Voi in 2015 to build the capacity of Kenyan technical workers (Daily Nation, 2015). Arguably, this is a tangible benefit on the continent where 60 percent of young people between the ages of 15 and 17 are not participating in any form of education (WENR, 2019). Likewise, this is an investment which creates several diverse forms of linkages, vital ones both short and long terms which go with the concept 
of backward and forward linkages; the more linkages that are created the better the investment is for Kenya and the continent at large. Forward linkages relate more to the long-term effect of capacity building and that the more engaged young people are especially with primary education, the more successful they will be in future. Though, investing in human capital, or training construction workers might not directly go in line with the theory of backward and forward linkages, but it does show that the outcome of the backward and forward linkages for building the SGR has a positive result on the general economy as people become educated, trained, acquire skills and gain future employment.

More so, it would be natural to assume that opportunities for construction-related local industries would be tremendous as demand for material such as cement, steel, railway sleepers, and sand needed for construction would surge. Wu et al. (2019) based on their interview confirm this hypothesis as the terms of the contract indicate that the SGR project is required to purchase all the construction material locally and utilize 40 percent of local content in terms of construction materials civil works, and job opportunities. This would create backward linkages to different sectors that can provide materials and goods required to complete the project. However, Wu et al. (2019) affirm that based on local entrepreneurs, including cement and steel manufacturers suggested a dissimilar reality by saying they could not compete with raw materials imported from China and were, therefore, losing business.

In addition, there are some serious challenges connected with operations of the SGR that impede its ability to realize its potential. According to Wu et al. (2019), the government forces them to use the SGR for key transportation between Mombasa ports to Nairobi even if this involves delays, thus distorting the logic of supply chains. The novel Nairobi clearing office is unable to handle snowballing cargo and when the cargo is not cleared in four days, the firm is burdened with onerous USD 25 per day fine. Although using the highway was more expensive than SGR, businesses had relationships with truck firms which ensured the fast and efficient movement of goods.

On top of that, within Kenyan society, the SGR is embroiled in multiple controversies typical of accusation against other Chinese mega-projects, including issues of economic viability, cost, debt sustainability, corruption, and opaque contracting and financing arrangements (Foster et al., 2009). During construction, complaints from the local community surfaced around issues of land compensation, environmental impacts, and imported sourcing of materials and labor. Notably, these complaints are explainable in part by stakeholders' failure to consult with local community needs. The author also suspects a tendency by several locals to demand more benefits from the project than is possible, an issue exploited by local politicians to extract political mileage out of the issues surrounding the SGR. Arguably, in most places, the ethnic and neo-patrimonial political culture is behind the controversies and the occasional violence. This is compounded by a deeply entrenched problem of corruption, rent-seeking and nepotism. ${ }^{21}$ With that said, given that these opportunities are created, the tougher job for the continent of Africa is to grow from them, try to manage ChinaAfrica relations via these opportunities, and maximize their gains.

\section{Case 3: Ghana's Bui Hydropower Dam}

Leaving the TAZARA and Mombasa-Nairobi Standard Gauge Railway facility and moving on to other hard infrastructure such as the Ghana Bui hydropower dam. Notably, the dearth of access to electricity across the continent of Africa is a crucial impediment to the continent's economic growth. The lack of power generation capacity, transmission, and distribution networks, as well as well-established utility frameworks, poses significant challenges to the continent of Africa socio-economic advancement. Based on the IEA report, the continent of Africa is home to nearly a fifth of the world's population, but accounts for less than 4 percent of global electricity use (IEA, 2019b). As a result, an appetite for large hydropower projects by African nations has increased significantly and created an opportunity for Chinese firms to build the much-needed power capacity in Africa. As a result, hydropower projects have become the preferred projects for Chinese contractors (see figure 9). The Chinese are involved in 52 percent of all hydropower projects in the region (in terms of capacity) followed by 29.3 percent involvement in coal projects and 10.7 percent in gas projects (Power Technology, 2019). Not only 
Figure 9. Power Generation Projects in Africa, Chinese Contractors vs Other Contractors (capacity additions, MW). Source: Power Technology, 2019.

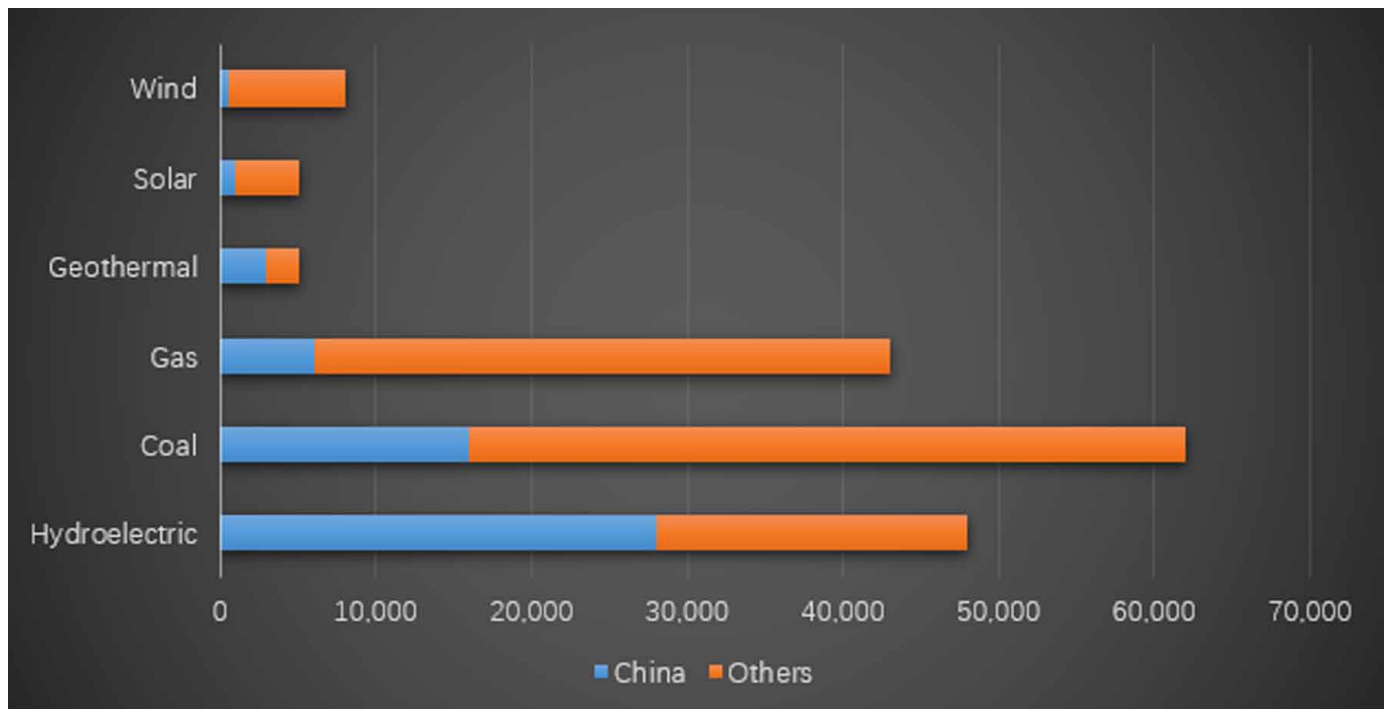

does this investment foster short-term direct linkages but also make people lives easier and perhaps snowballing their human capital by having access to electric power.

Speaking of a hydropower dam, the Ghana Bui hydropower dam is a collaborative project between the Ghanaian government and Sinohydro, a Chinese state-owned firm specializing in hydroelectric infrastructure projects. Completed in 2013, the Bui hydropower dam was constructed to address the electricity needs of Brong-Ahafo, Northern, Upper East, and Upper West regions, especially Brong-Ahafo and Northern regions, which are adjacent to the dam. The overall cost of the project reached US\$622 million, where the Export-Import Bank of China and the Ghanaian government were co-financiers, and Sinohydro was the contractor of the project. The Export-Import Bank of China disbursed two separate credit lines, one commercial and one concessional, of US\$292 million and US\$306 million, in 2008 and 2009 respectively. The Ghanaian government contributed a loan of US\$60 million as well (Chen and Landry, 2016). It is estimated that the dam will raise Ghana's electricity generation capacity by almost 20 percent.

Construction of the Bui Dam was anticipated to increase the nation's electricity generation capacity; nonetheless, it was not only about electrification. The Ghanaian government aimed to boost cocoa exports to China through the Bui Dam's loan pact. As stated initially, the Export-Import Bank of China provided two credit lines. To ensure reimbursement, the government agreed to secure the loans with cocoa; under their pact, a Chinese firm would purchase 30,000 tons of cocoa each year from Ghana at the world price until 5 years after the dam was operational. The payments for this cocoa would go directly to the Export-Import Bank of China. The remaining interest and principal of the loans would be repaid by 85 percent of the electricity sales (Tang and Shen, 2019). According to a World Bank report, the loan pact aligns with Ghana Poverty Alleviation Plan II and debt distress is at moderate risk (World Bank, 2008).

Based on Han report, the electricity output produced by the Bui Dam did not meet people's expectations (Han, 2018). The dam even temporarily stopped generating power shortly after it was put into use in June 2014. The Bui Power Authority claimed that the main causes behind the shutdown were a dearth of water in the reservoir as well as the Ghana Grid Company's intervention. The situation did not improve, and when major power outages hit in 2016, the government decided to import power from Cote d' Ivoire. Besides generation issues, transmission capacity was also worrisome. Ghana's 
electrical standards are not uniform. The power voltage of the dam was at $161 \mathrm{KV}$, while the standard used in the Upper West Region is 34.5KV. This situation led to two economic losses. First, Sinohydro had to invest more money in power voltage conversion facilities and second, these lower voltages augmented energy losses. More so, the nation was adopting an electricity voltage system at $330 \mathrm{KV}$, which meant that the Bui Dam had to adapt to the new standards as well.

Furthermore, Han affirms that the local community had a tough time benefitting from electricity produced by the dam for multiple reasons (Han, 2018). First, they had no electricity access before resettlement, which meant they did not own appliances or have prior experience using electricity. Second, resettled communities needed payment for linking to the grid, creating an additional barrier. Lastly, with the price of electricity snowballing locals had less incentive to buy electricity.

With that said, the Bui hydropower dam was not only about electrification as well as to boost cocoa exports to China, it was also about subcontracting arrangements, skills and technology transfers, and the procurement of materials and equipment. As for the aspect of subcontracting, literature on linkages in the construction industry recognizes subcontracting and other forms of cooperation, such as strategic alliances and joint ventures, the aspects of backward linkages (Polenske and Sivitanides, 1990; Devapriya and Ganesan, 2002). These collaborations facilitate technology and skill transfers, as well as knowledge development that is necessary to build local capacity and enhance the industry's competitiveness. Notably, Devapriya and Ganesan (2002) study on Sri Lanka and Ofori (2000) study on Singapore indicate that FDI represent a major modality for forging such linkages via collaboration with Japanese contractors.

Tsikudo (2019) affirms that despite these considerations, Sinohydro provided no subcontracts during the construction of the Bui dam. The author added that the Bui Power Authority (BPA) affirmed that it had a construction contract with Sinohydro and a timeline for the project. To ensure successful and on-time project completion, Sinohydro had to determine whether it wanted to subcontract part or all the project to hasten completion (Tsikudo, 2019). This BPA claims was confirmed by Sinohydro. More so, Tsikudo asserts that the official of Sinohydro affirmed that its contract with BPA was a construction arrangement with no subcontracting requirements. However, when asked whether they would have considered subcontracting if needed, the Sinohydro official answered: "Yes... an agreement is an agreement". Tsikudo affirms that the BPA officials explained their agreement with Sinohydro was not a Build Operate and Transfer (BOT) (Tsikudo, 2019). The Sinohydro contract only specified that Sinohydro had to develop a given project. Most contracts for major building projects, like the Bui hydropower dam, did not offer the contractor any responsibility beyond merely building the dam. The dearth of specificity in the original contract before the project even started stymied the benefits the Bui hydropower dam could have produced for the local economy.

With that said, while literature on Chinese construction companies' operations in Africa supports subcontracting to other Chinese companies, there is no robust proof of subcontracting to local contractors, especially without an explicit obligation to do so (Chen et al., 2009; Chen and Orr, 2009). This means that enforcing subcontracting with local contractors must originate from the project's contract in which all the modalities are clearly stated.

Although Sinohydro did not provide any subcontract to local contractors, they did so with other structural works. For example, a local contractor built a 15-kilometer access road within the project area. Additionally, local contractors constructed two resettlement camps for the displaced. These involved building facilities, like markets, schools, sanitation systems, and housing units. Local contractors also built a clinic, BPA's permanent staff village, and transmission lines (including pylons) connecting the powerhouse to substations in Sunyani. Local contractors who gained from these subcontracting arrangements highlighted the positive impact the project had on their operations, particularly finance (Tsikudo, 2019). Tsikudo gave an instance of how one contractor affirmed that "even though this is a government project, we do not have to mobilize funds for it like we frequently so with other government projects. Sinohydro paid us directly. Therefore, rather than moving from bank to bank soliciting mobilization, we just borrow or use what we have and get repayment...there 
is no delays in payment. Tsikudo added that in spite of the positive feeling some subcontractors lamented on the limited interactions they had with the Chinese contractor during their partnership as a result of language barriers (Tsikudo, 2019).

As for the aspect of procurement of material and equipment, Tsikudo asserts that heavy equipment, like bulldozers, copper wire, turbines, and steel for the project were sourced from Russia and China. Tsikudo confirms that a BPA official argued that "it is economically sensible to procure such equipment from abroad because there is no local supplier. The author added that another BPA official affirmed that "there was a 15-year gap between the Akosombo and Kpong Dams, and a 40-year gap between the Akosombo and Bui hydropower dams. A firm that specializes in the production of specialized dam materials runs the risks of losses" (Tsikudo, 2019). In addition to economic concerns, some experts questioned the quality of local supplies.

Bosshard (2009) argues China's construction industry is now competitive because of reforms it underwent during the 1990s. Chinese contractors spent years studying their Western counterparts while the government took time to identify the deficiencies, and enacted aggressive industrial policies to tackle the issues. This kind of industrial reorganization catapulted China into a global hydro dam developer. Although Sinohydro sourced electricity materials and heavy equipment from abroad, it procured materials, such as aggregates and cement, locally (Tsikudo, 2019).

In addition to electricity, boosting cocoa export to China, subcontracting and procurement, the construction and operation of the Bui hydropower dam was anticipated to directly provide 3,000 local jobs. Nevertheless, some commentators are worried about the labor force localization of Chinese firms in African nations. Kernen and Nam (2014) believe that even though Chinese firms actively invest in Ghana, complete localization of Chinese SOEs in Ghana does not yet exist. Though the Sinohydro hires local management staff, they are mostly employed for external operations, like sales and human resources, for the reason that the firm hopes to build a better image of engaging the local communities. This indicates how the degree of Chinese management localization can be limited.

Nonetheless, the study shows that the Bui Dam construction period, 2009-2013, needed up to 2,600 persons for 65 kinds of jobs. Of this number, 91 percent of employees were Ghanaian, who were employed as artisans, such as masons, carpenters, and electricians. Others were employed as casual laborers, including security guards, drivers, and manual daily wage workers and they were unskilled before the construction of the Bui dam. The remaining 9 percent employees were the Chinese (who never surpassed 400 employees) and Pakistanis (who were about 100 for specific position like machinery operators, welders, steel benders) and they constituted the expatriate quota allotted to the contractor (Hensengerth, 2011; Kirchherr et al., 2016; Han, 2018). The Ghanaians received three-stage training once employed. Karnen and Lam affirm that during onsite work, more skilled Chinese employees often supervised, mentored, and worked with local employees in groups for a period until the Ghanaians employees completely grasped techniques and skills for independent work (Kermen and Lam, 2014).

The construction project not only offered many job opportunities in the local community but transferred some technical skills to local employees as well. Construction labor experts view employment as a means of earning a livelihood and a way of developing people's skills (Ngowi, 2001). Therefore, employment in construction activities remains a critical conduit for linkages. The backward linkage involves upgrading workers' expertise. Forward linkages relate to the acquisition of novel ideas and skills that will benefit workers in other endeavors. These contributions and benefits from building the Bui dam regarding employment opportunities and skills transfer show that the forward linkage for snowballing labor are the skills these employees learnt and gain.

Alternatively, this could also be seen as a backward linkage because in order to build and improve the Bui dam the project will need workers and so people become an essential factor for the development of the project. More so, the construction and operation of the dam provide incomes for local Ghanaians workers. As such, the higher incomes that are induced through forward and backward linkages are often re-spent, generating a series of consumption expenditures. These multiplier effects 
are secondary benefits resulting from the Bui dam. While creating jobs opportunities, providing income, and transferring skills to the inhabitants is not only an investment for the project, it is also beneficial for the future Ghana economy.

Han affirms that the Bui Dam project management office set up a medical center onsite because of the high incidence of malaria and other waterborne diseases as well as the dearth of medical facilities in the region. To improve relations between expatriates and locals, the Chinese government also organized onsite recreational activities and made donations to local communities and schools. In case of infrastructure investments for the medical center, recreational activities, one input and emergence of a backward linkage to these medical center and recreational activities centers is labor because the medical center and recreational center will require workers.

Nonetheless, because of overtime work which the workers challenged the management is not in line with Ghana labor laws of working eight hours per day schedule, low wages, and dearth of secure leave, as well as health and safety risks, two strikes occurred in 2008 and 2013 (Chipaike and Bischoff, 2018). On top of that, local workers accused Sinohydro management of discrimination because of their counterparts from China were each given a room that was equipped with air-conditioners. The workers also complain of casualization ${ }^{22}$; Casualization is one legacy of the structural adjustment policy programs implemented in Africa during the 1980s and 1990s (Lee, 2009). It is a capitalist accumulation strategy of which the Chinese are taking advantage of. The process involves the offer of day jobs and fixed contracts without pensions or long-term security. The practice was widely used by Chinese firms and investors in Zambia and Tanzania (Lee, 2009). Although the practice is not uniquely Chinese, casualization has been adopted by Chinese firms on other parts of the continent of Africa.

Carmody (2011) considered the labor casualization phenomenon engaged by Chinese investors in Africa as a characteristic of feudalism. The author sees labor casualization as typical China's industrialization level. According to this view, China is at a development stage in which casualization seem tolerable. Carmody also indicates that nowadays industrialized nations engaged in similar behaviors in their early development stages. The African Labor Research Network (ALRN) considers casualization as exploitative and criticizes African governments' seemingly unconcerned attitude. ALRN observes that African governments' supine attitude stems from their fear of being viewed as less business-oriented and investor-friendly. More so, it affirms that African governments actively promote investment uncritically. The open-door approach to investments has deepened the casualization of African labor in Chinese firms in Africa. Casualization creates job insecurity and enervates collective bargaining aimed at improving working conditions. Casualization undercuts people's capability to upgrade their skills and seek better employment. As a result, a local labor union was set up in 2009. Sinohydro also signed a pact with Ghana's Trades Union Congress that demanded both employees and supervisors better understand their rights and obligations.

\section{CONCLUSION}

This paper has centered on China's engagement with Africa with respect to infrastructure projects. It is worth noting that the previous traditional models of infrastructure investment might perhaps be more connected to tied aid or resource-backed loans. Nonetheless, it has taken a long time before these forms of investments have shown any outcome and, therefore, the argument might be that it is time for African nations to step away from a traditional model to other alternatives such as what the Chinese are doing at the moment - it might be the best way for meeting Africa's needs.

With that said, by drawing instances upon diverse Chinese infrastructure projects in Africa, this paper has attempted to identify backward and forward linkages that have been created from Chinese infrastructure projects. The paper analyzed the developmental outcomes of the Tazara railway, Mombasa-Nairobi railway and Ghana Bui hydropower dam. It is worth noting that the Tazara railway, Mombasa-Nairobi railway and Ghana Bui hydropower dam can be conceptualized as cases of vested interests. The authorities in charge of the three different infrastructure projects sought their 
implementation to shore up the energy supply and bolster socioeconomic transformation. In addition to these goals, these three different projects were expected to provide employment, irrigation, ecotourism, and socioeconomic infrastructure respectively within these three diverse projects areas. On top of that, the study discovers that skills amongst workers' spillover to other businesses and firms, it is worth noting that competition in local markets can push local firms to invest in novel technologies. With these goals, the Tazara railway, Mombasa-Nairobi railway and Ghana Bui hydropower dam can be interpreted as having multiple gains and linkages for and beyond the three various projects areas.

Nonetheless, the three various projects were seen by Chinese government to fulfill its objectives in Africa. How these goals were attained is a function of state capacity. As the analysis shows, most of the benefits for these three nations have been patchy. There was no subcontracting for stakeholders in Ghana Bui hydropower dam. Although some materials were procured locally, it was only done because import seemed costlier. The general process of procurement regarding these three projects implementation flouted the local procurement law, for instance, in the Ghana Bui hydropower dam (Tsikudo, 2019). The Tazara railway, Mombasa-Nairobi railway and Ghana Bui hydropower dam also created a lot of labor uneasiness and anxiety via casualization, which caused employees insecurity, and hence limited backward and forward linkages. Although this is a rare case as well as some would argue that relationship between China and Africa is mostly a toxic one, by drawing upon different instances of infrastructure projects it can be demonstrated that some significant outcomes are being made in this sector were backward and forward linkages are created and offers new opportunities for African nations to advance.

Linkages are crucial; nonetheless, only a purposive state can induce, nurture, and sustain them. The state-centered framework requires active state intervention to shape the outcomes of China-Africa engagements. For African nations to create linkages using Chinese infrastructure investments, it requires a change in philosophy. African nations cannot continue to uncritically promote and support Chinese initiatives. The existing open-door policies need to give way to a more productive approach in which African nations objectives are integrated into proposed China-funded projects. The goal for African government is to make sure that the relationship continues to be cooperative to circumvent exploitation at any times.

In conclusion, to tie this final mark together this paper has attempted to demonstrate what role the Chinese-led infrastructure projects play in African infrastructure development and what the infrastructure investment leads to concerning creating new opportunities and businesses for Africa, and as the final analysis reveals by drawing upon the three different infrastructure cases - currently the relationship is considered to be a cooperative one were both Africa and China are winning from it. 


\section{REFERENCES}

AfDB. (2013). Supporting the Transformation of the Private Sector in Africa: Private Sector Development Strategy, 2013-2017. African Development Bank Group. Retrieved 10 January, 2020 from https://www.afdb.org/ fileadmin/uploads/afdb/ Documents/Policy-Documents/2013-2017_-_Private_Sector_Development_Strategy. pdf

AfDB. (2018). African Economic Outlook 2018. Retrieved July 2, 2019, from www.afdb.org/en/ Knowledge/ publications/african-economicoutlook/

African Development Bank (AfDB), Organization for Economic Co-operation and Development (OECD) Development Centre, \& United Nations Development Programme (UNDP). (2014). Africa Competitiveness Report 2014. Geneva: World Economic Forum.

Atsushi, L., Richard, M. H., \& Yonas, E. L. (2017). Model Choice between Rail and Road Transportation: Evidence from Tanzania. Policy Research Working Paper, WPS8174. World Bank. Retrieved 21 June, 2019 from documents.worldbank.org/curated/en/7337 81504010382743/pdf/WPS8174.pdf

AUC/OECD. (2018). Africa's Development Dynamics 2018: Growth, Jobs and Inequalities. OECD Publishing.

Bond, J. (2016). Infrastructure in Africa. Global Journal of Emerging Market Economies., 8(3), 309-333. doi: $10.1177 / 0974910116677788$

Bosshard, P. (2009). China Dams the World. World Policy Journal, 26(4), 43-51. doi:10.1162/wopj.2010.26.4.43

Brautigam, D. (2009). The Dragon's Gift: The Real Story of China in Africa. Oxford University Press.

Brautigam, D. (2019). Chinese Loans and African Structural Transformation. In A. Oqubay \& J. Y. Lin (Eds.), China-Africa and Economic Transformation (pp. 129-270). Oxford University Press. doi:10.1093/ oso/9780198830504.003.0007

Business Daily. (2017). SGR Maintenance Training for 2,000 Youth. Retrieved 17 January, 2020 from https:// www. Businessdailyafrica.com/magazines/SGR-maintenance-training-for-2-000-youth/1248928-3521000135upskz/index.html

Calabrese, L., Gelb, S. \& Hou J. (2017). What Drives Chinese Outward Manufacturing Investment? A Review of Enabling Factors in Africa and Asia. Background Paper. Supporting Economic Transformation (SET).

Carmody, P. (2011). New Scramble for Africa. Polity.

Castellano, A., Kendall, A., Nikomarov, M., \& Swemmer, T. (2015). Powering Africa. McKinsey.

Chen, C., Goldstein, A., \& Orr, R. J. (2009). Local operations of chinese construction firms in Africa: An empirical survey. International Journal of Construction Management, 9(2), 75-89. doi:10.1080/15623599.2009.10773131

Chen, C., \& Orr, R. J. (2009, November 1). Chinese Contractors in Africa: Home Government Support, Coordination Mechanisms, and Market Entry Strategies. Journal of Construction Engineering and Management, 135(11), 1201-1210. doi:10.1061/(ASCE)CO.1943-7862.0000082

Chen, M. X., \& Lin, C. (2018). Foreign Investment Across the Belt and Road: Patterns, Determinants and Effects. World Bank. Retrieved 2 June, 2019 from http://documents. Worldbank.org/curated/en/394671539175518256/ pdf/WPS8607.pdf

Chen, W., \& Nord, R. (2018). China and Africa: Whither the Belt and Road? Retrieved 7 April, 2019 from https://www.ictsd.org/bridges-news/bridges-africa/news/china-and-africa-whither-the-belt-and-road

Chen, Y., \& Landry, D. G. (2016). Capturing the Rains: A Comparative Study of Chinese involvement in Cameroon's Hydropower Sector. China Africa Research Initiative, Working Paper No. 2016/16.

Chipaike, R., \& Bischoff, P. H. (2018). A Challenge to Conventional Wisdom: Locating Agency in Angola's and Ghana's Economic Engagements with China. Journal of Asian and African Studies, 53(7), 1-16. doi:10.1177/0021909618763922

Dadvar, B. (2016). China's Role in African Infrastructure Development: Cooperation or Exploitation? Lund University School of Economics and Management. 
Daily Nation. (2015). Chinese Firm Launches Railway Training Facility. Retrieved 28 December 2019 from https:// www.nation.co.ke/business/Chinese-firm-launches-railway-training-facility/996-2774228-vbb9bz/index.html

Deloitte. (2018). If You Want to Prosper, First Build Roads: Africa Construction Trends Report 2018. Author.

Deloitte. (2019). Africa in 2019 Outlook, Summary Report. Retrieved 12 July, 2019 from https://www2.deloitte. com/content/dam/Deloitte/za/Documents/africa/za_africa_in_2019_outlook_summary_report_022019.pdf

Devapriya, K. A. K., \& Ganesan, S. (2002). Technology transfer through subcontracting in developing countries. Building Research and Information, 30(3), 171-182. doi:10.1080/09613210110117593

Donghai, Y. (2016). Why the Chinese Sponsored the TAZARA: An Investigation about the People's Republic of China's African Policy in the Regional Context, 1955-1970. Retrieved 7 January, 2020 from asianstudies.buffalo. edu/wp-content/uploads/sites /58/2016/08/NYCAS-Donghai-Yu.pdf

Dynamar. (2018). West Africa Container Trades (2018). Retrieved 21 December, 2019 from https: //www. dynamar.com/publications/207

Ehizuelen, M. M. O. (2017). Education and Skills Development in China-Africa Cooperation. Frontier Education China, 13(4), 553-600. doi:10.1007/s11516-018-0030-0

EXIM Bank. (2018). Connecting Africa: Role of Transport Infrastructure. Export-Import Bank of India, Working Paper No.72.

Fine, B., \& Rustomjee, Z. (1996). The Political Economy of South Africa: From Minerals-Energy Complex to Industrialization. Hurst.

Foster, Butterfield, \& Chen. (2008). The Changing Landscape of Infrastructure Finance in Africa: Non-traditional Sources Take on a Growing Role. The World Bank Public-Private Infrastructure Advisory Facility (PPIAF).

Foster and Briceño-Garmendia. (2010). Africa Infrastructure: A Time for Transformation. Africa Development Forum Series. The World Bank. Retrieved 19 January, 2018 from https://documents.worldbank.org/curated/ en/2009/01/11487313/africasinfrastructure-time-transformation

Global Railway Review. (2017). Kenya Railway's Standard Gauge Railway. Kenya Railway's Standard Gauge Railway. Retrieved 5 January, 2020 from https://www. Global railway review.com/article/61059/kenya-railwaysstandard-gauge-railway/

Godfrey, S., \& Ross, A. (2016). China and Africa: The New Water World. Waterlines, 35(1), 12-17. doi:10.3362/1756-3488.2016.003

Guo, D. (2013). Comparison of Economic Linkages between China and Africa: Applying the WIOD database. United Nations Industrial Development Organization, Working Paper.

Hallegatte, S., Rentschler, J., \& Rozenberg, J. (2019). Lifelines: The Resilient Infrastructure Opportunity. Sustainable Infrastructure. World Bank. doi:10.1596/978-1-4648-1430-3

Han, X. (2018). Money, Markets and Hydropower: Chinese Dam Construction in Africa, Minerva Access. Ashgate. Retrieved 20 December, 2019 from minerva-access.unimelb.edu.au/handle/11343/208834

Hensengerth, O. (2011). Interaction of Chinese Institutions with Host Government in Dam Construction: the Bui dam in Ghana. Academic Press.

Hirschman, A. (1958). The Strategy of Economic Development. Yale University Press.

Hirschman, A. O. (1969). The Strategy of Economic Development. Oxford Press.

Hirschman, A. O. (1981). Essays in Trespassing: Economic to Politics and Beyond. Cambridge University Press Archive.

IEA. (2014). Africa Energy Outlook - A Focus on Energy Prospects in Sub-Saharan Africa. World Energy Outlook Series, OECD/IEA.

IEA. (2015). World Energy Outlook. OECD/IEA. 
IEA. (2019a). Africa Energy Outlook 2019. International Energy Agency (IEA). Retrieved 11 January, 2020 from www.fondem.ong/wp-content/uploads/2019/11/Africa_Energy_Outlook_2019.pdf

IEA. (2019b). World Energy Outlook 2019. International Energy Agency (IEA). Retrieved 15 January, 2020 from https://www.iea.org/reports/world-energy-outlook-2019

IEA \& UIC. (2015). Railway Handbook 2015: Energy Consumption and CO2 Emissions. OECD International Energy Agency and International Union of Railways.

Infrastructure Consortium for Africa (ICA). (2017). Infrastructure Financing Trends in Africa. Retrieved 26 June, 2019 from https://www.icafrica.org/fileadmin/documents/Annual_Reports/IFT2017.pdf

International Monetary Fund (IMF). (2014). World Economic Outlook. IMF.

Jesse, G., \& Madden, P. (2019). Figures of the Week: Africa's infrastructure needs are investment opportunity. Brookings.

Kaplinsky, R., \& Morris, M. (2001). A Handbook for Value Chain Research. IDRC.

Kenya China Economic and Trade Association. (2017). 2017 Chinese Enterprises in Kenya Social Responsibility Report. Retrieved 22 December 2019 from http://ke2.mofcom

Kenya National Bureau of Statistics. (2019). Economic Survey 2019. Retrieved 10 January, 2020 from https:// www.knbs.or.ke/download/economic-survey-2019/

Kermen, A., \& Lam, K. N. (2014). Workforce Localization among Chinese State-Owned Enterprises (SOEs) in China. Journal of Contemporary China.

Kinyondo, Y. J., \& Chatama, G. (2015). Impact of China's Cooperation: The Case of Chinese Garages in Tanzania. Journal of Chinese Economic and Foreign Trade Studies, 8(1), 27-39.

Kirchherr, J., Disselhoff, T., \& Charles, K. (2016). Safeguards, Financing, and Employment in Chinese Infrastructure Projects in Africa: The Case of Ghana's Bui Dam. Waterlines, 35(1), 37-58.

Kopp, Block, \& Limi. (2013). Turning the Right Corner: Ensuring Development through a Low-Carbon Transport Sector. World Bank.

Kou, S. (2018). China is Investing in Africa and that is a Good Thing. Business Day. Retrieved 9 May, 2019 from https://www.businesslive.co.za/bd/opinion/2018-12-19-china-is-investing-in-africa-and-thats-a-good-thing/

Krugman, P. (1991). Increasing Returns and Economic Geography. Journal of Political Economy, 99, 483-499.

Kummritz, V., Taglioni, D., \& Winkler, D. (2017). Economic Upgrading through Global Value Chain Participation. Policy Research Working Paper No. 8007. Washington, DC: World Bank.

Lee, C. K. (2009). Raw Encounter: Chinese Managers, African Workers and the Politics of Casualization in Africa's Chinese Enclaves. The China Quarterly, 199, 647-666.

Lomas, N. (2012). Innovate or Die: Nokia's Long-Drawn-Out Decline. Techcrunch. Retrieved July 12, 2018 from https://techcrunch.com/2012/12/31/nokias-long-drawn-out-decline/

Mckinsey Global Institute. (2016). Bridging Global Infrastructure Gaps. Collaboration with Mckinsey's Capital Projects and Infrastructure Practice. Retrieved 6 May, 2018 from https://www.un.org/pga/71/wp-content/uploads/ sites/40/2017/06/Bridging-Global-

Monson, J. (2009). Africa's Freedom Railway: How a Chinese Development Project Changed Lives and Livelihood in Tanzania. Indiana University Press.

Monson, J. (2013). Remembering Work on the Tazara Railway in Africa and China, 19652011: When "New Men" Grow Old. African Studies Review, 56(1), 45-64.

Morlin-Yron, S. (2017). China Funds Railways to Link Across East Africa. Retrieved 12 January, 2018 from https://www.cnn.com/2016/11/21/Africa/Chinese-funded-railways-in-africa

Morris \& Fessehaie. (2014). The Industrialization Challenge for Africa: Towards a Commodities based industrialization path. Journal of African Trade, 1, 25-36. 
Moyo, D. (2009). Dead Aid: Why Aid Is Not Working and How There Is a Better Way for Africa. Farrar, Straus, and Giroux.

Mtegha, H., Leeuw, P., Naicker, S., \& Molepo, M. (2012). Resources corridors: Experiences, Economic and Engagement; A Typology of Sub-Saharan African Corridors. School of Mining Engineering and Centre for Sustainability in Mining and Industry (CSMI). University of Witwatersrand.

Mutethya, E. (2018). CRBC Sends Third Batch of Kenyan Students to Study in China. China Daily. Retrieved 25 December, 2019 from http://global.chinadaily.com.cn/a/201804/21

New Partnership for Africa's Development (NEPAD). (2015). Infrastructure Development: Within the Context of Africa's Cooperation with New and Emerging Development Partners. Office of the Special Advisor on Africa. OSAA.

Ngowi, H. P. (2001). Can Africa Increase its Global Share of Foreign Direct Investment (FDI)? West Africa Review, 2(2), 1-20.

OECD. (2018a). Enhancing Connectivity through Transport Infrastructure: The Role of Official Development Finance and Private Investment, The Development Dimension. OECD.

OECD/IEA. (2014). Africa Energy Outlook: A Focus on Energy Prospects in Sub-Saharan Africa: World Energy Outlook Special Report. OECD Publishing/International Energy Agency. Retrieved 30 December from www. iea.org/publications/freepublications

Park, S. H. (1989). Linkages between Industry and Services and their Implications for Urban Employment Generation in Developing Countries. Journal of Development Economics, 30(2), 359-379.

Perkins, D., \& Robbins, G. (2011). The Contribution to Local Enterprise Development of Infrastructure for Commodity Extraction projects: Tanzania's Central Corridor and Mozambique's Zambezi Valley. MMCP Discussion Paper 9. The Open University and University of Cape Town.

Pham, J.P., Abdoul S.B., \& Boubacar, B. (2018). Chinese Aid and Investment are Good for Africa. Foreign Policy. Retrieved 6 June, 2019 from https://foreignpolicy.com/2018

Polenske, K. R., \& Sivitanides, P. (1990). Linkages in the construction sector. The Annals.

Sender, J., \& Smith, S. (1986). The Development of Capitalism in Africa. Methuen.

Shapshak, T. (2018). How Mobile Money Continues to Boom in Africa. Forbes. Retrieved 25 June, 2019 from https://www.forbes.com/sites/tobyshapshak/2018/11/27/how-mobile-money-continues-to-boom-inafrica/\#6fb0880c5c

Sow, M. (2018). Figures of the Week: Africa's Intra-and Extra-regional Trade. Brookings. Retrieved from 29 March, 2018 from https://www.brookings.edu/blog/africa-in-focus/2018/03/29/figures-of-the-week-africasintra-and-extra-regional-trade/

Sun, Y. (2017). China and the East Africa Railways: Beyond full Industry Chain Export. Brookings. Retrieved 10 January, 2020 from https://www.brookings.edu/blog/africa-in-focus/2017/07/06/china-and-the-east-africarailways-beyond-full-industry-chain-export/

Sy Amadou, N. R. (2017). Leveraging African Pension Funds for Financing Infrastructure Development. African Growth Initiative at Brookings.

Tang, K., \& Shen, Y. (2019). Do China-Financed Dams in Sub-Saharan Africa Improve the Region's Social Welfare? A Case Study of the Impacts of Ghana's Bui Dam. Working Paper No. 2019/25. China Africa Research Initiative, School of Advanced International Studies, John Hopkins University.

Technology, P. (2019). China Continues to Build Much-Needed Power Capacity in Africa. Retrieved July 2, 2019 from https://www.power-technology.com/comment/chinese-investment-in-africa-2019/

The African Capacity Building Foundation. (2016). Infrastructure Development and Financing in Sub-Saharan Africa: Towards a Framework for Capacity Enhancement. Occasional Paper No. 25.

Timo \& McKibbin. (2010). The Economics of Infrastructure in a Globalized World: Issues, Lessons, and Future Challenges. June, Brookings Institution. 
Todaro, M. P., \& Smith, S. C. (2009). Economic Development (10th ed.). Addinson-Wesley.

Tompsett, D. (2018). Africa's Growth Story: The Exploitation of a Continent. Vision. Retrieved from https:// www.vision.org/fr/exploitation-of-africa-8304

Tregenna, F. (2008). Sectoral Engines of Growth in South Africa: An Analysis of Services and Manufacturing. Research Paper/UNU-WIDER, No.2008.98.

UN-Habitat. (2014). The State of African Cities 2014: Re-imagining Sustainable Urban Transitions. United Nations Human Settlements Programme. Retrieved 15 January, 2020 from http://mirror.unhabitat.org/pmss/ getElectronic Version.aspx? $\mathrm{nr}=$

United Nations Conference on Trade and Development (UNCTAD). (2008). World Investment Report: Transnational Corporations, and the Infrastructure Challenge. Geneva: UNCTAD.

Wade, S. (2019). What China is Really Up to in Africa? Forbes. Retrieved 4 October, 2019 from https://www. forbes.com/sites/wadeshepard/2019/10/03/what-china-is-really-up-to-in-africa/\#686a067f5930

Walker, M., \& Jourdan, P. (2003). Resource-based Sustainable Development: An Alternative Approach to Industrialization in South Africa. Minerals and Energy - Raw Materials Report, 18(3), 25-43.

WENR. (2019). New Benefactors? How China and India are Influencing Education in Africa. World Education News+Review (WENR). Retrieved 8 June, 2019 from https://wenr.wes.org/2019/04/how-china-and-india-areinfluencing-education-in-africa

World Bank. (1984). The Construction Industry: Issues and Strategies in Developing Countries. The World Bank.

World Bank. (2008). International Development Association Program Document for a Proposed Credit in the Amount of SDR60.8 million (US\$100 million equivalent) to the Republic of Ghana for a Sixth Poverty Reduction Support Credit. Author.

World Bank. (2012). Transformation through Infrastructure. World Bank.

World Bank (2017a). The Global Findex Database 2017: Measuring Financial Inclusion and the Fintech Revolution. Washington, DC: World Bank.

World Bank. (2017b). Why we need to close the infrastructure gap in Sub-Saharan Africa. Washington, DC: World Bank. Retrieved 12 May, 2019 from https://www.worldbank.org

Wu, T., Gomera, J., \& Vaidyanathan, V. (2019). Connectivity and Transport Infrastructure. In China's Infrastructure Development in Africa: An Examination of Projects in Tanzania and Kenya. Institute of Chinese Studies.

Xinhuanet. (2019). Tanzanian FM Hails Bilateral Ties with China. Retrieved 10 July, 2019 from www.xinhuanet. com/english/2019-04/05/c_137953116.htm

\section{ENDNOTES}

1 Deloitte Africa, “Africa Construction Trends”, 2018. Retrieved 2 May, 2019 from www2.deloitte.com/ za/en/pages/energy-and- Resources/articles/africa-construction-trends-report.html

2 Methods using more available data show that for advanced economies, an increase in one percentage point of GDP in investment spending in advanced economies raises the level of GDP by about 0.4 percent in the same year and by 1.5 percent four years after the increase.

3 Additionally, closing the infrastructure gap relative to global best performers could see the growth effect upsurge GDP per capita by 2.6 percentage points per year. World Bank (2017). Africa Pulse. Retrieved 26 June, 2019 from http://www.worldbank.org/en/region/afri/publication/why-we-need-to-close-theinfrastructure-gap-in-sub-saharan-africa.

4 Raw material supply. Retrieved 29 December, 2019 from https:/www.sciencedirect.com/topics/economicseconometrics-and-finance/raw-material-supply

5 Economies of scope. Retrieved 5 January, 2020 from https://www.sciencedirect.com/topics/economieseconometrics-and-finance/economies-of-scope 
Agglomeration effect. Handbook of regional and urban economies, 2015. Retrieved 5 January, 2020 from https://www. sciencedirect.com/economics-econometrics-and-finance/agglomeration-effect

PWC. 2014. Trends, challenges and future outlook. Capital projects and infrastructure in East Africa, Southern Africa and West Africa. PWC Africa.

Basel III: Need to know. Euromoney. Retrieved 24 January, 2020 from https://www.euromoney.com/ article/b12kjsv4trtmdl/basel -iii-to-know

http://www.nepad.org/regionalintegrationandinfrastructure

(EAC, Undated)

https://www.sadc.int/english/regional-integration/is/

www.comm.ecowas.int/dept/stand.php?id=f_f1_brief\&lang=en

United Nations Economic Commission for Africa

https://www.afdb.org/en/topics-and-sectors/infrastructure/

L. Modowo, “Should Africa be wary of Chinese debt?", BBC, 2018. Retrieved June 14, 2019 from www. bbc.com/news/world- africa-45368092

Deloitte Africa, "Africa Construction Trends", 2018, www2.deloitte.com/za/en/pages/energy-andresources/articles/africa-construction-trends-report.html.

Liu Haifang \& Jamie Monson, "Railway Time: Technology Transfer and the Role of Chinese Experts in the History of Tazara," in African Engagements, eds. Ton Dietz, Kjell Havnevik, Mayke Kaag, and Terje Oestigaard (Brill, 2011), 226-251.

L. Corkin, C. Burke \& M. Davies, "China's Role in the Development of Africa's Infrastructure," Working Papers in African Studies, 2008, https://www.sais-jhu.edu/sites/default/files/China's-Role-in-theDevelopment-of-Africa's-Infrastructure.pdf.

Kenyan standard-gauge railway nears completion. International Railway Journal, April 28, 2016. Retrieved from: https://www.railjournal.com/index.php/africa/kenyan-standard-gauge-railway-nears-completion. html?channel $=$

China-aided trans-Africa railway line likely to transform regional trade. Nikkei Asian Review. Retrieved 16 January, 2019 from https://asia.nikkei.com/Economy/China-aided-trans-Africa-railway-line-likely-totransform-regional-trade

21 Bach (2013) reviews the old concept of patrimonialism in an international, not exclusively African context and points to the mixed and ambivalent nature of neo-patrimonialism. In his view of neo-patrimonialism in the state rather than the patrimonial state per se, personalized power relations and appropriation of state resources co-exist with legal-rational and developmental models of public policy. Our research on the SGR finds precisely a mixture of such processes; Daniel Bach, "Régimes politiques, pratiques systémiques et dynamiques de l'émergence dans les états africains et post-soviétiques" [Political Regimes, Systemic Practices and Dynamics of Emergence in African and Post-Soviet States], Revue internationale de politique compare [International Review of Comparative Politics] 20, no. 3 (2013): 153-169; Michaela Wrong, It's Our Turn to Eat: The story of a Kenyan whistleblower (London: Fourth Estate, 2009).

A process whereby employees are employed in causal and temporary capacity instead of being permanent staff. 